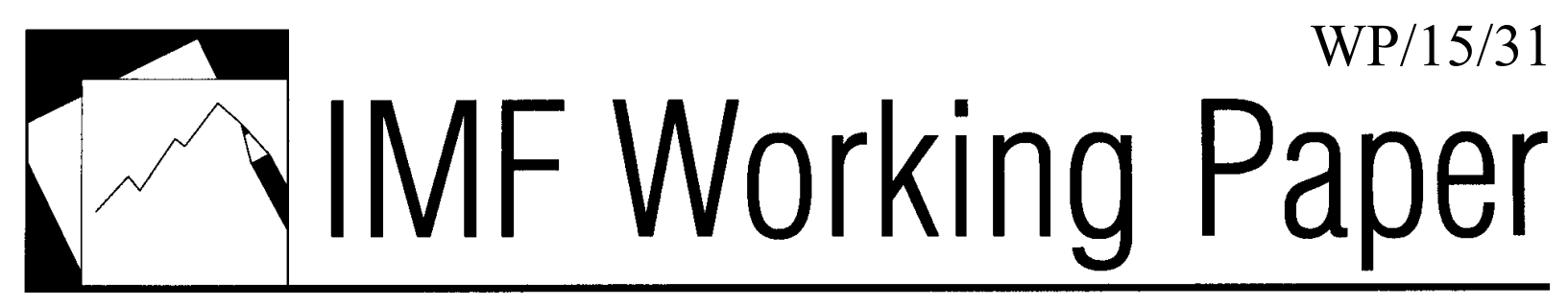

\title{
Can Islamic Banking Increase Financial Inclusion?
}

Sami Ben Naceur, Adolfo Barajas, and Alexander Massara 


\title{
IMF Working Paper
}

Middle East and Central Asia

\section{Can Islamic Banking Increase Financial Inclusion?* \\ Prepared by Sami Ben Naceur, Adolfo Barajas, and Alexander Massara}

Authorized for distribution by Zeine Zeidane

February, 2015

IMF Working Papers describe research in progress by the author(s) and are published to elicit comments and to encourage debate. The views expressed in IMF Working Papers are those of the author(s) and do not necessarily represent the views of the IMF, its Executive Board, or IMF management.

\begin{abstract}
The paper analyses existing country-level information on the relationship between the development of Islamic banking and financial inclusion. In Muslim countries-members of the Organization for Islamic Cooperation (OIC) - various indicators of financial inclusion tend to be lower, and the share of excluded individuals citing religious reasons for not using bank accounts is noticeably greater than in other countries; Islamic banking would therefore seem to be an effective avenue for financial inclusion. We found, however, that although physical access to financial services has grown more rapidly in the OIC countries, the use of these services has not increased as quickly. Moreover, regression analyis shows evidence of a positive link to credit to households and to firms for financing investment, but this empirical link remains tentative and relatively weak. The paper explores reasons that this might be the case and suggests several recommendations to enhance the ability of Islamic banking to promote financial inclusion.
\end{abstract}

JEL Classification Numbers: E44; E52; F6; G2; O16

Keywords: Islamic banking, financial inclusion, Financial Possibility Frontier

Authors’ E-Mail Addresses: Abarajas@,imf.org, Sbennaceur@,imf.org and Amassara@imf.org

\footnotetext{
** The authors would like to thank Hanan AbuShanab for providing drafting and other inputs on an earlier version of this paper and to Ramsey Andrawis, Lisa Dougherty-Choux, Mbaye Gueye, and Jing Lu for their excellent research assistance. The authors thank Martin Cihak, Ananthakrishnan Prassad, Abdikaram Farah, Afzal Norat, Dr. Abdullah I. El-Kuwaiz, the Islamic Financial Services Board (IFSB), and Zeine Zeidane for their excellent comments on previous drafts, and to seminar attendants of the Interdepartmental Working Group on Islamic Finance on November 10, 2014 for their valuable input. We also thank Amin Mohseni-Cheraghlou for providing access to the Islamic Banking Database. Kia Penso and Cecilia Prado de Guzman provided excellent editorial assistance.
} 


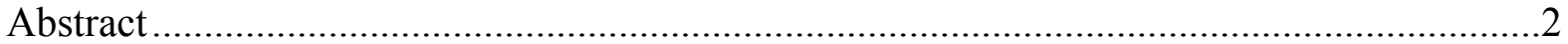

I. Introduction: Is Islamic Banking A Possible Avenue for Increasing Financial Inclusion?...4

II. Stylized Facts: Trends and Cross-Country Comparisons of Financial Inclusion..................7

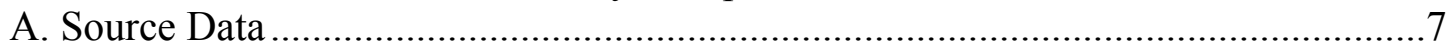

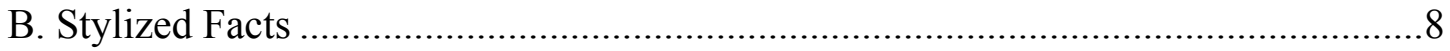

III. Is There an Empirical Relationship Between Islamic Banking and Financial Inclusion?.13

Do the cross-country differences continue to hold once all relevant structural

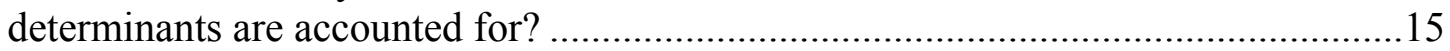

IV. Policies for enhancing financial inclusion................................................................ 19

A. Constraints and Potential for Access to Finance................................................20

B. Policies to Foster Access through Islamic Finance ............................................21

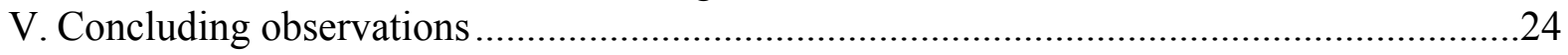

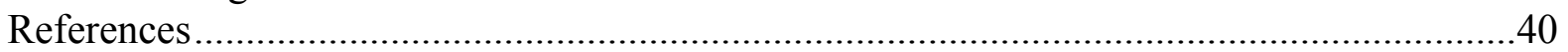

Tables

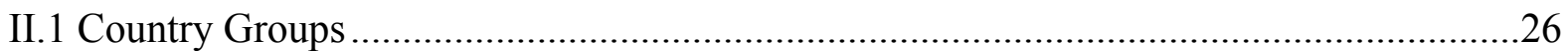

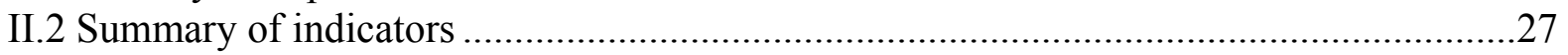

II.3 Mean growth rates and levels for selected variables..............................................28

II.4 Summary of differences in Means Comparisons (Selected Indicators) .........................29

II.5 Differences in Financial Access and Depth between OIC and Other Countries...............30

II.6 Differences in Financial Access and Depth between OIC and Other Countries and

Within OIC Between Islamic Banking Countries and the Rest .......................................31

III.1 Cross-Country OLS Estimation of the Effect of Islamic Bank Presence and

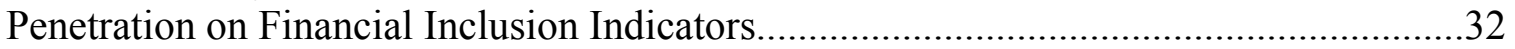

III.2A Cross-Country OLS Estimation of the Effect of Islamic Bank Presence and Penetration on Financial Inclusion Indicators, Expanded Set of Controls .......................33

III.2B Cross-Country OLS Estimation of the Effect of Islamic Bank Presence and Penetration on Financial Inclusion Indicators, Expanded Set of Controls .......................34

III.2C Cross-Country OLS Estimation of the Effect of Islamic Bank Presence and Penetration on Financial Inclusion Indicators, Expanded Set of Controls ........................35

III.2D Cross-Country OLS Estimation of the Effect of Islamic Bank Presence and Penetration on Financial Inclusion Indicators, Expanded Set of Controls .......................36

III.2E Cross-Country OLS Estimation of the Effect of Islamic Bank Presence and Penetration on Financial Inclusion Indicators, Expanded Set of Controls ........................37

III.2F Cross-Country OLS Estimation of the Effect of Islamic Bank Presence and Penetration on Financial Inclusion Indicators, Expanded Set of Controls ........................38

III.3 Cross-Country OLS Estimation of the Effect of Islamic Bank Presence and Penetration on Financial Inclusion Indicators amd Their Structural Benchmarks 


\section{Introduction: Is Islamic BANKIng A Possible AVEnUe for InCREASIng FINANCIAL INCLUSION?}

Financial inclusion has become an increasingly important concern for a vast number of countries worldwide. At the same time that a fast-growing literature has emerged to examine its measurement, determinants, and impacts, governments have made promoting it a priority. For example, the World Bank's 2014 Global Financial Development Report (GFDR), devoted to financial inclusion, reports that more than two-thirds of regulatory and supervisory agencies have been tasked with encouraging financial inclusion, and more than 50 countries have set formal targets. Last year the World Bank President announced a global target of universal financial access by 2020.

Defined as the share of the population who use financial services, ${ }^{2}$ financial inclusion has proven to be linked to desirable economic outcomes above and beyond those associated with the more familiar concept of financial depth. At the micro level, several studies show evidence that access to savings accounts at the local level produces benefits to the directly affected population by increasing savings, investment, consumption, or income. Several case studies have documented how increased access to credit has led to increases in entrepreneurship and reductions in poverty, as a result of a relaxation of financing constraints that are especially binding on smaller and younger firms in developing countries. ${ }^{3}$ At the macro level, although evidence is lacking of a robust and direct link between financial inclusion and nationwide outcomes such as economic growth, income equality, or poverty reduction, there is some indirect or suggestive evidence. One study shows that the wellknown positive association between financial depth ${ }^{4}$ and long-term economic growth is consistently weaker in certain groups of countries - the Middle East and North Africa (MENA), low-income countries, and oil exporters - all of which also tend to underperform in financial inclusion, that is, exhibit lower levels of financial inclusion when compared to countries with similar financial depth. Thus, there may be a cost in foregone economic growth when the volume of financial services in a country does not reach a sufficiently large share of the population (Barajas, Chami, and Yousefi, 2013). Additionally, Bhattacharaya and Wolde (2010) found that lack of access to credit was one factor driving down growth in MENA countries relative to the rest of the world.

\footnotetext{
${ }^{2}$ This is a useful definition because it can be measured and incorporated easily into theoretical and empirical work. It has been adopted by the World Bank 2014 Global Financial Development Report (GFDR). There have been other definitions proposed in the literature, such as "access to financial services", "responsible and sustainable provision of financial services", "affordable delivery to disadvantaged and low-income segments of society," "broad range of services of high quality, with attention to consumer protection". All capture key aspects of financial inclusion, but the definition adopted in this paper allows for measurement on a comparable basis across countries.

${ }^{3}$ These studies are reviewed in Chapter 1 of the 2014 GFDR.

${ }^{4}$ Usually measured as the volume of a given financial service, such as credit to the private sector, relative to GDP.
} 
The literature has identified several factors that promote financial inclusion across countries. First are structural factors, which primarily determine the costs of providing financial services to the population. For example, a geographically small country with its residents concentrated in a few urban centers will find it much less costly to extend financial services throughout the population than a large country with a dispersed population; thus financial inclusion will naturally tend to be higher in the former. ${ }^{5}$ Second, policy-related factors have also been found to be relevant in creating an enabling environment for financial inclusion; Love and Martínez Pería (2012) show that bank competition is linked to greater financial inclusion: all else being equal, in countries with more competitive banking systems - as measured by a lower Lerner index - a greater share of firms has access to a loan, overdraft, or bank credit line. Love, Martínez Pería, and Singh (2013) find that the introduction of movable collateral registries increases firms' use of credit and reduces the degree to which firms consider access to finance to be an obstacle to their growth prospects. Third, some nonpolicy characteristics are also relevant: for example, for sub-Saharan Africa, Aga and Martinez Pería (2014) show that inflows of international remittances play a part as well; remittance-recipient households are more likely to have a bank account, once individual characteristics such as household income and education level are controlled for.

Increasing financial inclusion often amounts to reducing two types of exclusion: involuntary and voluntary. The factors described above relate to involuntary exclusion - the share of the population that would like to have access and use financial services but do not, for various reasons - but there are also individuals who choose not to use financial services. Based on household survey information in the Global Findex database, spanning 149 countries and more than 124,000 individuals, ${ }^{6}$ it is estimated that more than half of the world's adult population does not have an account with a formal financial institution; a non-negligible proportion of these might be without such an account by choice. For example, about 30 percent of these unbanked cited lack of sufficient funds as the sole reason why they did not have a formal account, 23 percent cited the fact that someone else in the household had an account and therefore they did not need one, ${ }^{7}$ and about 5 percent cited religious reasons for not having a formal account.

Worldwide financial exclusion for religious reasons seems relatively small, but the share varies notably across countries and can be particularly high in certain Muslim countries. For

\footnotetext{
${ }^{5}$ The distinction between structural and nonstructural factors determining financial inclusion will be discussed further in Section B.

${ }^{6}$ The sampling was done to achieve national representation of 97 percent of the world population. See Demirguc-Kunt and Klapper (2012) for a detailed description of the Findex database, and Allen, DemirgucKunt, Klapper, and Martínez Pería (2012) for regression analysis using this data to study the determinants of ownership and usage of banking accounts throughout the world. This study relied on individual respondent data, and therefore was forced to exclude several countries from the analysis because of missing respondent-level data. However, as our study focuses on country-level averages, the missing respondent-level data do not affect our analysis, and we were able to retain these countries in our work.
}

${ }^{7}$ As Allen and others (2012) point out, these respondents might be considered indirect users of financial services rather than completely unbanked. 
example, the share of adults citing religious reasons for not having an account is 34 percent in Afghanistan, 26-27 percent in Iraq and Tunisia, and 23-24 percent in Djibouti and Saudi Arabia. ${ }^{8}$ However, other Muslim countries exhibit relatively low levels of religious selfexclusion: virtually zero in Malaysia, 21/2-3 percent in Kuwait and the United Arab Emirates, and $4 \frac{1}{2}$ percent in Sudan.

The rapid growth of Islamic finance throughout the world in recent years - with assets of Islamic financial institutions more than doubling since $2006^{9}$-raises the key question: to what extent has it contributed to financial inclusion by reducing the incidence of religious self-exclusion in Muslim countries? This question is particularly relevant given that research cited earlier has indicated that certain regions and groups of countries with sizable Muslim populations - MENA oil exporters, for example - have tended to underperform on financial inclusion, and that this underperformance may be linked to costs in the form of lower longterm economic growth.

In this paper we analyze the existing country-level information on both financial inclusion and the penetration or presence of Islamic banking, to ascertain the extent to which Islamic banking has contributed to financial inclusion. The World Bank 2014 GFDR presents some encouraging results: Islamic banking is found to be positively related to financial inclusion; while Muslim countries in general tend to exhibit lower levels of financial inclusion, Islamic banking is associated with a lower incidence of religious self-exclusion and with a lower share of firms citing access to finance as a significant obstacle. However, there is also reason for caution. Using micro-level data, Demirguc-Kunt, Klapper, and Randall (2013) find that, once relevant individual characteristics are accounted for, although Muslims are less likely to have an account or save in a formal financial institution, they are no less likely to borrow from one, and the greater observed religious self-exclusion of Muslims seems to arise solely in sub-Saharan African countries. Furthermore, the authors do not find evidence that the size of the Islamic finance industry is related to differences in financial inclusion between Muslims and non-Muslims. ${ }^{10}$

\footnotetext{
${ }^{8}$ To clarify, the figures refer to the respondents who cited religious reasons for not having an account, as a percentage of those who reported not having an account, not as a percentage of total respondents.

${ }^{9}$ Mohielden and others (2011).

${ }^{10}$ In that study, separate analysis on a more limited country sample — five Muslim countries—may shed additional light on these issues; 48 percent of adult respondents reported being aware of Islamic banks, and only 2 percent report using a Shari'ah-compliant banking service. When presented with the choice between two hypothetical loans - one Shari' ah-compliant and a cheaper conventional loan -45 percent of respondents preferred the former.
} 
The approach of this paper is to test for a possible financial inclusion-Islamic banking relationship across a wide variety of measures of both. Section II focuses on supply-side data contained in the IMF's Financial Access Survey (FAS) with some additional analysis using the user-side financial inclusion databases. Although FAS data have certain limitations-for example, it does not directly survey households or firms - it does allow one to track trends over time, because this survey has been conducted since 2004. Therefore, Section II examines the extent to which Islamic banking is associated with trends in supply-side measures of financial inclusion in Muslim countries. Section III conducts two types of test. First, it tests whether user-side measures of financial inclusion from the Global Findex dataset are related to different measures of Islamic banking: the number of Islamic banks or the total size of assets of Islamic banks, measured in relation to the adult population, the total size of the banking industry, or GDP. The second test assesses the extent to which the above relationship holds up once structural determinants of financial inclusion are accounted for, by using the financial inclusion measures that have been "benchmarked" by these structural determinants. Finally, Section IV summarizes policy implications for enhancing financial inclusion in Muslim countries, using lessons drawn from the empirical analysis as well as from the existing literature on Islamic banking. First, to the extent that the paper's analysis supports a relationship between Islamic banking and (some measures of) financial inclusion, the simplest policy recommendation is to promote the development of Islamic banking. Second, to the extent that limitations or weaknesses are revealed in the relationship, the paper draws on recent studies that suggest an avenue to enhance the ability of Islamic banking to promote inclusion, specifically among small and medium-sized enterprises (SMEs). Admittedly, here the paper is on less solid ground, because the arguments are not backed up strictly by cross-country empirical analysis but rather by case studies and more anecdotal evidence. Finally, Section IV also refers to proven policies for enhancing financial inclusion in general, regardless of whether the banking industry contains Islamic banks.

\section{Stylized Facts: Trends And Cross-Country Comparisons of Financial INCLUSION}

In this section we describe the main trends and regularities observed in both supplier and user-side data of financial inclusion, making comparisons across broad groups of countries, distinguishing between Muslim countries - defined as members of the Organization for Islamic Cooperation (OIC) — and others, and, within the group of OIC countries, between those with active Islamic banking sectors and those without (Table II.1).

\section{A. Source Data}

The main data source used for our analysis is the IMF's Financial Access Survey (FAS). ${ }^{11}$ The FAS database comprises comparable indicators on access to and use of financial services provided by financial institutions to resident households and nonfinancial corporations for 189 countries around the world. The FAS is a supplier-side survey, in that the data are

\footnotetext{
${ }^{11}$ The FAS database is available via the FAS website (http://fas.imf.org/).
} 
collected from the suppliers of the financial services. The database contains approximately 150 time series and 50 key indicators, which are grouped into two dimensions: (i) geographic outreach of financial services; and (ii) use of financial services. The database currently contains annual data for the period 2004-13. The survey also provides a breakdown of the users of financial services by households and SMEs.

We sourced two additional sets of financial inclusion data from the World Bank: the Global Financial Inclusion Index (Global Findex) and the Enterprise Survey databases. The former is a triennial household survey, first conducted in 2011, on the use of financial services; the latter is a firm-level survey conducted on a country-by-country basis every three to five years. The Enterprise Survey covers several topics, one of which is access to finance. As opposed to the FAS, these datasets are user-side surveys of financial inclusion. They offer more granular data at the expense of country coverage and periodicity. As such, the Findex and Enterprise Survey data serve as a complement to the FAS.

\section{B. Stylized Facts}

In this section, we present some stylized facts on growth rates and levels of a selected group of indicators taken from the abovementioned datasets. To compare the growth rates, we examine a subset of FAS indicators and look at average year-on-year growth over the 10-year period (2004-13). To analyze the relative levels of financial inclusion, we used the World Bank's Global Findex and Enterprise Survey data, where only one year of data is available. Table II.2 presents a summary of the indicators examined in this section.

Using these variables, we investigated the relationship between Islamic banking and financial inclusion by comparing the difference in means of two different country groupings. We start with the $57 \mathrm{OIC}$ member countries and compare the means of selected financial inclusion variables to those in non-OIC countries. To further isolate the impact of Islamic banking on financial inclusion, we conducted a second comparison whereby we divided the OIC members into two groups: those with Islamic Banking and those without. ${ }^{12}$ To compare the groups, we use a two-sample t-test on the difference in mean growth rates (FAS) and levels (Global Findex and Enterprise Survey).

\section{Decade-Long Trends in Financial Inclusion Observed in Supplier-Side Data}

For the world as a whole, we found that the majority of financial inclusion indicators grew steadily throughout the past decade, with growth rates slowing in the aftermath of the global financial crisis. However, when comparing growth rates of the various country groups, we observed some significant divergences. Regarding the geographic outreach of financial

\footnotetext{
${ }^{12}$ We determine this breakdown using the World Bank's Islamic Finance database. Among the 57 OICV countries, 36 are classified as Islamic banking countries as well. Table II.2 provides a list of these countries.
} 
services, we found that the OIC group as a whole shows significantly faster growth than the rest of the world, while OIC countries without Islamic banking have experienced faster growth rates in a number of variables. For example, among OIC countries over the observed period, average growth in ATMs was significantly higher, at nearly 20 percent annually, while the rest of the world averaged growth of 11 percent, as shown in Fig II.1. The OIC group also experienced growth rates in commercial bank branches that were twice as high ( 8 percent) compared to the rest of the world (4 percent). Within

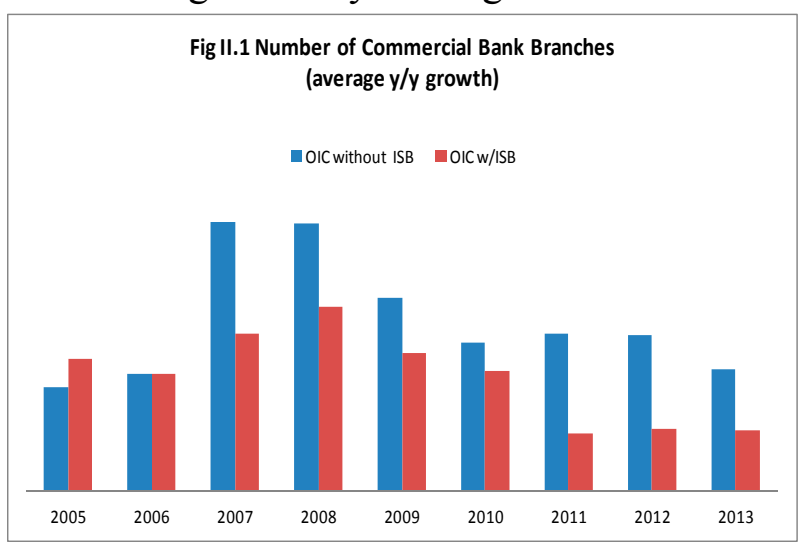
the OIC countries, growth in bank branches averaged more than 10 percent, while OIC countries with Islamic banking grew at just 7 percent, as shown in Fig II.1. Similarly, OIC countries without Islamic banking experienced significantly faster growth in commercial bank deposit accounts (12 percent) than OIC countries without Islamic banking (8 percent), as shown in Fig II.2. OIC countries without Islamic banking also experienced faster growth in both total borrowers and total loan accounts (16 percent and 14 percent, respectively) versus OIC countries with Islamic banking (10 percent and 8 percent, respectively).

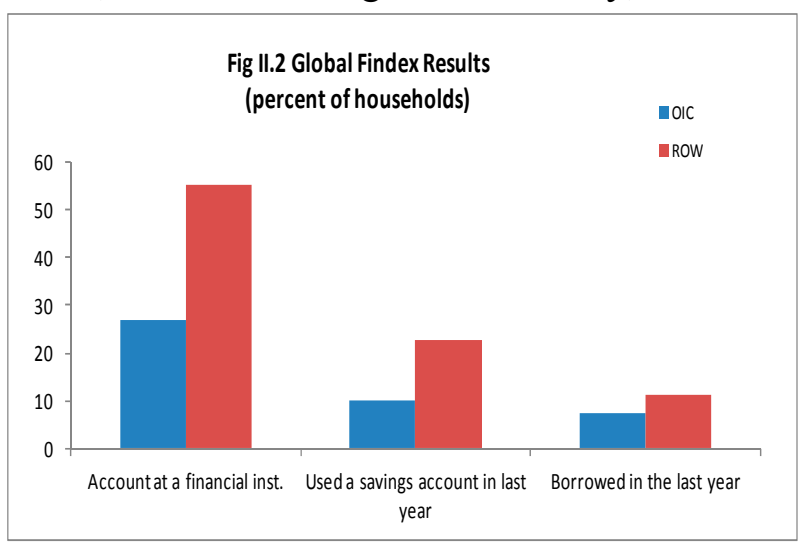

Grouping countries by income level ${ }^{13}$ yields additional noteworthy insights with respect to financial inclusion and Islamic banking. For the majority of the selected financial inclusion indicators, low- and lower-middleincome countries show higher average growth than upper-middle- and high-income countries. These results generally hold within the OIC group as well. We see this, for example, when we analyze average growth in commercial bank depositors as compared with the world average. Except in

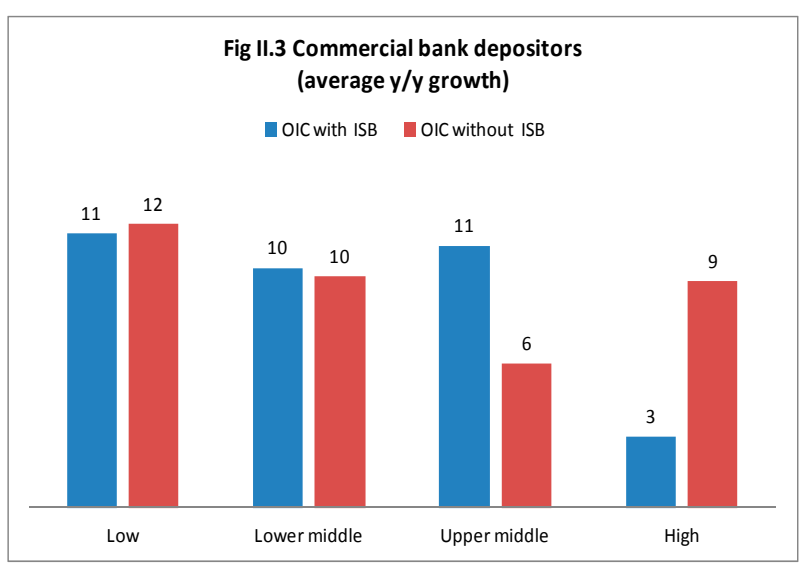
high-income OIC countries with Islamic banking, the number of depositors tended to grow faster in the low- and lower-middle-income groups (Figure II.3).

\footnotetext{
${ }^{13}$ We used the World Bank's World Development Indicators database to determine country income group classifications.
} 
A number of the differences in mean growth rates across countries turned out to be statistically significant (Table II.4). OIC countries outperformed the rest of the world in growth of bank branches, ATMs, and deposit accounts, while the opposite was true for small and medium-sized enterprise (SME) depositors. Within OIC countries, those without Islamic banking registered significantly higher growth rates in bank branches, deposit accounts, percentage of bank borrowers, and outreach of loan accounts. However, as the next subsection will show, these higher growth rates within OIC countries constitute a partial catch-up of the nonIslamic banking OIC countries, because recent levels of most indicators of financial inclusion are still higher for the Islamic banking OIC countries.

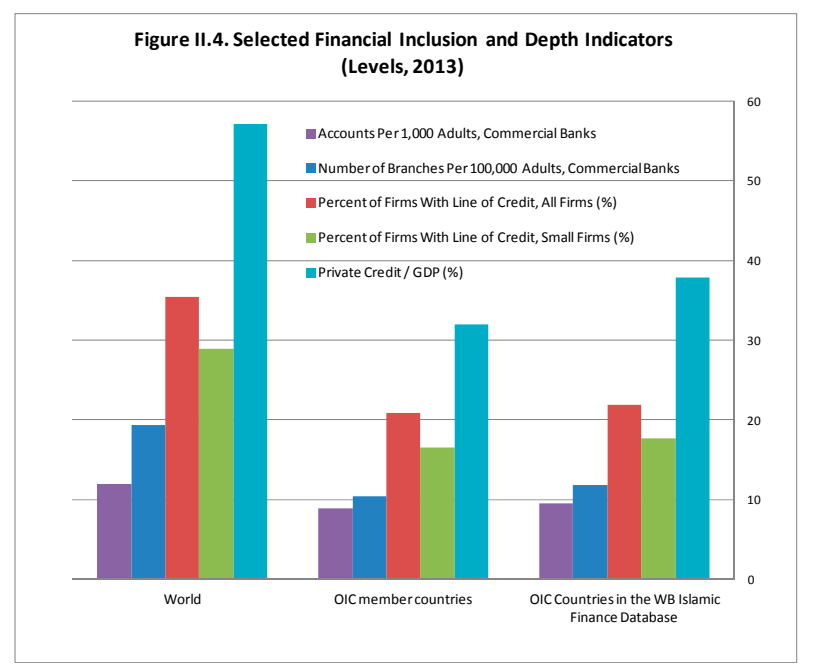

\section{Comparing Recent Levels of Financial Inclusion, Using Both Supplier and User-Side Data}

A first pass at the data suggests that populations of Muslim countries on average have less access to financial services and make less use of them than in the rest of the world. Figure II.4 displays four measures of inclusion as of $2013:{ }^{14}$ the number of commercial bank accounts per 1,000 adults, and the percent of firms with either a loan or a credit line, for all firms and for small firms. For comparison, also displayed is the ratio of private sector credit to GDP, which is primarily a measure of financial depth, but also tends to be positively correlated with the measures of inclusion. While the world as a whole averages just less than 12 accounts per 1,000 adults, OIC member countries average about $83 / 4$ accounts. On average, about 35 percent of firms worldwide report having a loan or line of credit from a formal financial institution, whereas the average for OIC countries is less than 21 percent. Similarly, the OIC average depth, at 32 percent of GDP, is 25 percentage points below the world average.

The broad averages also suggest that Islamic banking may be playing a role in Muslim countries: the OIC countries with Islamic banking, exhibit average levels of inclusion and depth that surpass those of the typical OIC country. For example, the OIC Islamic banking countries show an average use of loans for small firms of $171 / 2$ percent, about 1 percentage point greater than the OIC average. Likewise, depth, at 38 percent, is 6 percentage points of GDP greater in the OIC Islamic banking countries.

\footnotetext{
${ }^{14}$ Similar patterns in the data are observed when comparing averages over 1998-2013.
} 
These general patterns continue to hold for other financial inclusion indicators. On household use of financial services, Figure II. 5 shows that in OIC countries a smaller percentage of adults have accounts or have received loans from formal financial institutions than in the rest of the world, and both percentages are visibly higher for the Islamic Banking subgroup, particularly in the case of the use of accounts. As mentioned in the Introduction, religious self-exclusionthe percentage of adults citing religious reasons for not having an account-is noticeably higher in OIC countries, $9^{1 / 4}$ percent compared to the worldwide average of $51 / 2$ percent. Interestingly, though, it is higher still for the Islamic

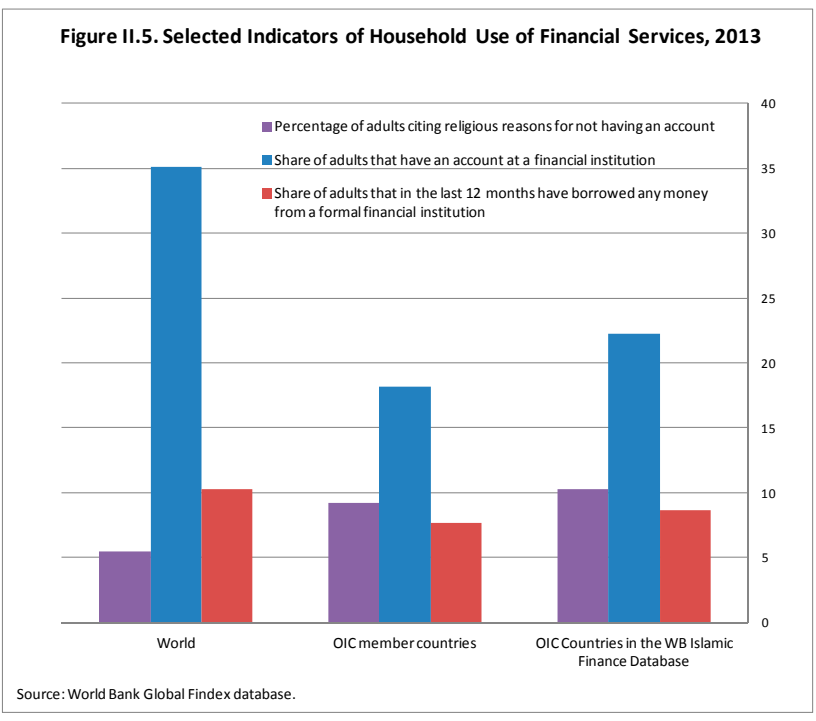
Banking Countries within OIC, at 101/4 percent. Firms' use of bank financing for investment and working capital is also lower in OIC countries, as shown in Figure II.6. On average, 17 percent of OIC firms use bank loans to finance investment, compared to a worldwide average of $25^{1} / 2$ percent. The corresponding figures for the percentage of working capital funded by banks are $241 / 4$ percent for OIC and $321 / 4$ percent for the worldwide average. Finally, OIC firms are more likely to view access to credit as a major obstacle to their growth prospects, by 7 percentage points. As for the OIC Islamic banking countries, they outperform the OIC average with regard to bank funding of investment, but underperform with regard to funding of working capital.

However, this first pass of the data does not address two key issues. First, it is unclear whether the observed differences across groups of countries are statistically significant. Second, it is well known that financial access and depth are highly

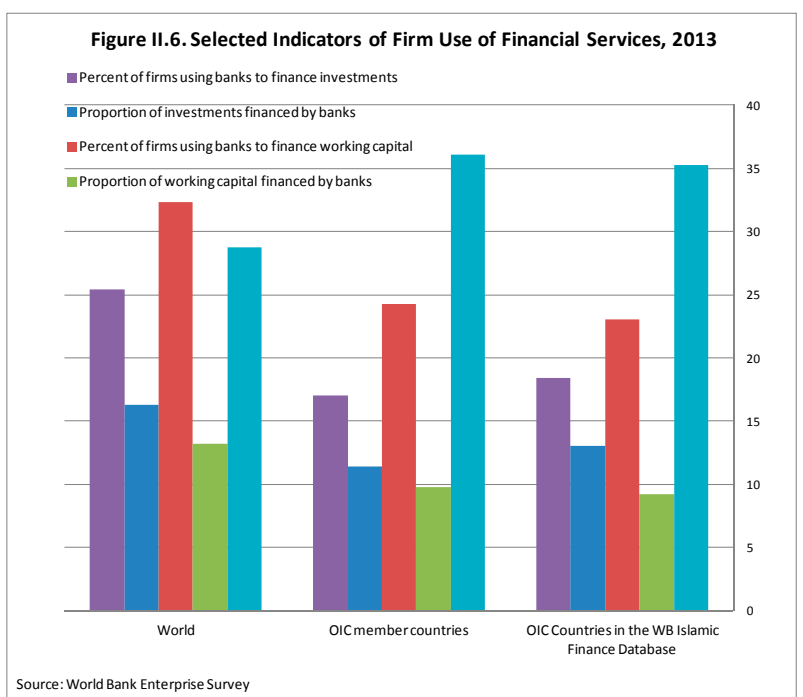
dependent on structural or non-policy factors such as income per capita, and therefore the cross-country differences observed earlier could be merely reflecting differences in these factors. To answer the first question, we first computed t-tests of differences in means (Table II.4), then conducted two types of regressions: ${ }^{15}$ (i) a cross-country regression in which a single observation of each financial access and depth variable for each country was run

\footnotetext{
${ }^{15}$ As shown in Table III.1, there were two versions of this equation. First, the observations of the dependent variable were taken at their average over 1998-2013; or, second, only the last observation available was taken.
} 
against a constant and an OIC dummy variable; and (ii) a fixed-effects regression in which all available country and time observations were included.

Table II.5 summarizes the results of a first set of regressions that essentially conducts means differences tests comparing OIC to other countries, and shows that financial inclusion in the former group is significantly lower ; for example, OIC countries exhibit on average between 400 and 450 fewer accounts per 1,000 adults, 12 fewer branches per 100,000 adults, and about 20 percentage points lower use of credit by all firms and 16-17 percentage points lower for small firms. Furthermore, financial depth is also significantly lower in OIC countries by some $25-35$ percentage points of GDP.

A second set of regressions conducts a slightly more detailed test of differences in means, assessing whether the observed differences within the group of OIC countries - between those classified as Islamic Banking Countries and the rest-are significant, controlling for country income per capita as a response to the question of whether structural factors might be explaining differences across groups of countries. The regression equation is specified as:

$$
F I_{i}=\beta_{0}+\beta_{1} y_{i}+\beta_{2} O I C_{i}+\beta_{3}\left(O I C_{i} \cdot W B I B_{i}\right)
$$

That is, each financial inclusion indicator FI is regressed on income per capita $y$, a dummy $O I C$ indicating whether country $i$ is a member of OIC, and the interaction of the OIC dummy with a dummy variable $W B I B$ indicating whether the country is classified as an Islamic Banking country. For those $F I$ variables for which there are multiple time observations, the last available observation was taken. ${ }^{16}$ The results, shown in Table II.6, continue to give strong evidence that financial inclusion in OIC countries is significantly lower than in the rest of the world; households are less likely to own accounts or borrow from banks and are more likely to cite religious reasons for not having accounts, while firms - both large and smallare less likely to borrow from banks in general and to finance investment in particular, and are more likely to identify access to finance as a major constraint. Furthermore, as expected, country income is a determining factor in financial inclusion as well: it is associated with a greater proliferation of accounts and bank branches, more extensive use of accounts and bank loans by households and of loans by firms, and a lower perception of financing constraints. Interestingly, income is not significantly related to religious self-exclusion.

Looking at differences within the OIC grouping, however, does not reveal any distinct advantage of the Islamic Banking countries. Although the coefficients of the interaction between $O I C$ and $W B I B$ are generally of the same sign as in the means differences tests in Section II-indicating that OIC Islamic Banking countries display greater access and use of financial services by households and firms and a lower perception of financing constraints by firms - they do not achieve statistical significance in any of the regressions, even when the

\footnotetext{
${ }^{16}$ Similar results were obtained when the dependent variable is measured as an average over the past five years of observations.
} 
simple difference in means was statistically significant, as reported in Table II. $4^{17}$. Thus, the observed differences in means may have been partly attributable to differences in income per capita.

However, it is presumed that Islamic banks have not reached the same level of development across these countries; therefore we go one step further in the next subsection, investigating whether the degree of presence or penetration of Islamic banks has had an impact on financial inclusion in the OIC countries.

\section{IS THERE AN EMPIRICAL RELATIONSHIP BETWEEN ISLAMIC BANKING AND FINANCIAL INCLUSION?}

In this section, we focus on the relative performance of countries with substantial Muslim populations with regard to financial inclusion, that is, access to and use of financial services and, more specifically, how this performance is gauged once structural characteristics are accounted for. Thus, two key questions are of interest: (i) Does the presence and/or activity of Islamic Banks play a visible role in enhancing inclusion? (ii) Does the answer to this question change once other structural or nonpolicy factors affecting inclusion are taken into account?

The section presents the main findings on each of the above questions, and provides a brief discussion of the conceptual framework underlying the distinction between actual and structurally-determined levels of financial access across countries, namely the Financial Possibilities Frontier.

We draw on two types of indicators of Islamic banking: the number of Islamic banks operating in the country, and the size of assets of these banks. These indicators can then be scaled by one or more of the following: total population, number of adults, total assets of the banking system, or total number of banks. Admittedly, the data on Islamic banking are imperfect because there is no single accepted definition of an Islamic bank; nor is there a single, comprehensive database. We used three main sources: (i) Bankscope, which provides balance sheet information for reporting banks classified as Islamic; (ii) the Islamic Banking Database created by the World Bank, ${ }^{18}$ which contains a wider coverage of Islamic financial institutions, including some banks that offer a combination of conventional and Shari'ahcompliant services and products, and (iii) whenever possible, various central banks of the corresponding countries. ${ }^{19}$

\footnotetext{
${ }^{17} \mathrm{We}$ also ran similar regressions in which the group of Islamic Banking countries within OIC was limited to those in which Islamic banks had a market share of at least 2 percent. The results were unchanged: the Islamic banking countries, once controlling for income level, did not display higher levels of financial inclusion.

${ }^{18}$ See http://go.worldbank.org/AE0U8AYQ20. The version consulted for this paper had been updated as of February, 2014.

${ }^{19}$ Two types of imperfections or incompleteness in the data can be identified. First, the Bankscope data, though complete in the sense that balance sheet information is available for all reporting institutions, might underestimate both the number and total assets of Islamic banks because of the existence of nonreporting
} 
The regression equation we analyzed is similar to equation (1), but substitutes an Islamic Banking indicator $I B$ in place of the Islamic Banking dummy variable $W B I B$. The subscript $j$ denotes the specific Islamic banking measure being used. Note that a simplified version of this equation was run on the sample of OIC countries only, where the OIC dummy variable drops out and the interaction term reduces to the Islamic banking variable $I B_{j}$. Note also that we replace $y$ with $X$ in the specification, to show that we include an expanded set of controls; in addition to income per capita, we also control for indices of legal rights, credit information, and banking sector competition. ${ }^{20}$

$$
F I_{i}=\beta_{0}+\beta_{1} X_{i}+\beta_{2} O I C_{i}+\beta_{3}\left(O I C_{i} \cdot I B_{j i}\right)
$$

Table III.1 shows the results of the first set of these estimations, controlling only for income per capita ${ }^{21}$ and focusing on two IB measures: $I B_{0}$, the total number of Islamic banks (indicating presence), and $I B_{1}$, their total assets (indicating activity), both scaled by the adult population. ${ }^{22}$ For comparison, the measures drawn from two primary data sources of these variables are shown: Bankscope and the World Bank Islamic Banking Database. As in the previous two tables, financial inclusion variables, along with the Islamic banking variables, are evaluated at their last observation.

The results confirm that, across both supply-side and user-side indicators, OIC countries in general exhibit lower financial inclusion, and income per capita is a significant determinant of financial inclusion, associated with more extensive networks of bank branches, wider use of accounts and credit, and lower perceived obstacles to financing for firms. On the possible empirical link between Islamic banking presence and activity and financial inclusion, the evidence is mixed. Islamic banking in OIC countries is associated with greater use of bank

Islamic banks, or because its definition of Islamic banks is relatively narrow. Second, although the World Bank Islamic Database might measure the total number of Islamic financial institutions more accurately, it tends to understate total assets because data are lacking on some of the institutions it classifies as Islamic. As mentioned above, an effort was made to supplement these two sources with official country data, but gaps still remain.

${ }^{20}$ The legal rights index ranges from 0 (weak) to 10 (strong), and that of depth of credit information ranges from 0 (shallow) to 6 (deep). Both were obtained from the World Development Indicators. The index of competition used is the estimated Lerner index of banking sector pricing markup over cost, with a higher value indicating lower competition. It was obtained from Global Financial Development Database.

${ }^{21}$ Other, unreported, regressions control for a wider range of structural variables: the square of real income per capita (in addition to its level), population size and density, young and old age dependency ratios, and dummy variables for transition economies, offshore financial centers, and fuel exporters. The results regarding the OIC variable and its interaction with the Islamic banking variable were broadly the same, but the significance of income per capita declined visibly. Because it was difficult to find a set of structural variables that were consistently significant across all regressions, we opted to report this parsimonious specification in which the structural variables are summarized by income per capita. The following subsection examines results on a limited number of financial inclusion indicators for which the number of observations over time allows for a full benchmarking exercise based on all structural factors.

${ }^{22}$ Similar results were obtained when scaling by total population or as a share of total number of banks or total assets of the banking system. 
credit by households and by firms, primarily for investment purposes. Interestingly, though, there is no significant association with ownership of accounts by households, the incidence of religious self-exclusion, nor with firms' perception that there are obstacles to financing.

These results continue to hold after we include additional "enabling environment" controls. Tables III.2A-F show the results of equation (III.2) including the legal rights, credit information, and bank competition measures, in addition to controlling for income per capita. ${ }^{23}$ While income per capita continues to be significant throughout, there is only a weak positive association between Islamic banking and the percentage of firms with bank credit, although the association with the use of bank credit by households and with firms' financing of investment continues to be significant. Furthermore, these results show that stronger legal rights and higher-quality credit information are associated with a greater share of adults borrowing from or holding accounts in formal financial institutions. The quality of credit information is also associated with a higher share of firms using bank credit and a lower share citing lack of access to finance as an obstacle. The effect of bank competition is less clear; it is associated with lower perceived financing obstacles and may be associated with a wider branch network and a greater share of adults owning accounts, but these latter associations are never statistically significant, and competition seems to be negativelythough not significantly - related to other measures of financial inclusion. ${ }^{24}$

The final subsection examines some of these relationships once all relevant structural factors - those not influenced by policy — are accounted for.

\section{Do the cross-country differences continue to hold once all relevant structural determinants are accounted for?}

The final question we address in this section is whether some of the observed patterns in the data might change once a wider set of structural factors underlying financial inclusion are controlled for. To provide a conceptual background, the following discussion centers on a useful analytical framework, the Financial Possibilities Frontier. ${ }^{25}$

Because of the particular functions and nature of finance, overall development of the financial sector - in both depth and inclusion - is constrained by two types of factors. One type comprises time-invariant or structural characteristics such as income per capita,

\footnotetext{
${ }^{23}$ As in footnote 19, there are unreported versions of these regression results in which a broader set of structural variables is included, and the results were similar.

${ }^{24}$ Part of the reason for the relative weakness of some of these controls may be related to their correlation with income per capita. In separate regressions, in which these three controls were included and income per capita was not, the sign and significance of all three pointed to a stronger association with financial inclusion. For example, the share of firms citing lack of access to finance as an obstacle was negatively associated with both legal rights and the quality of credit information, and positively associated with the Lerner index. These results are available upon request.

${ }^{25}$ This discussion draws heavily on Barajas and others (2013).
} 
population size and density, and the degree of economic informality, all of which jointly determine the viable market size for financial institutions and services. The second type are policy factors, such as the degree of macroeconomic stability and the supporting legal and institutional framework that can either increase or reduce the costs and risks of providing financial services, and therefore further determine the extent of financial activity in an economy. Thus, a given indicator of either financial depth or inclusion can be seen as the result of both structural and policy factors. A simple graphical example can illustrate this point: consider a financial inclusion proxy, such as the number of bank loans per 1,000 adults. ${ }^{26}$ The greater the size of the economy and the population and its density, the more cost-effective it becomes for the banking system to provide loans to broader

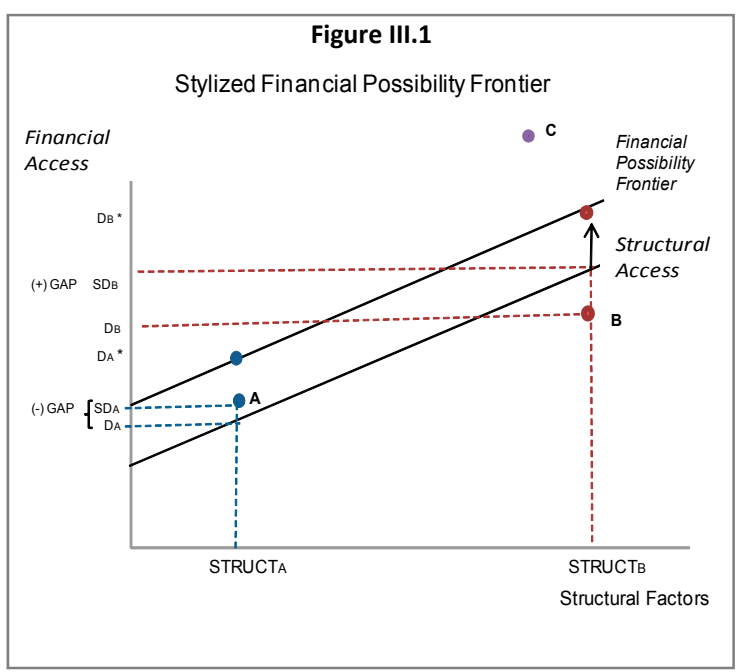
swaths of the population. Therefore, as in Figure III.1, one would expect a positive relationship between this access measure on the vertical axis and the structural characteristics summarized along the horizontal axis. This average relationship is given by the Structural Access line ${ }^{27}$ Country A, which is relatively small and low-income, and has a highly dispersed population (all summarized as $\mathrm{STRUCT}_{\mathrm{A}}$ ) should be expected to have a lower level of inclusion than Country B, a high-income, large country with its population concentrated in a few urban centers (summarized by STRUCT $\mathrm{S}_{\mathrm{B}}$ ). However, policy and the enabling environment play an important role as well. For example, as a result of pro-finance policies, Country A is able to exceed its "structural benchmark," registering a level of inclusion $\mathrm{D}_{\mathrm{A}}$, greater than $\mathrm{SD}_{\mathrm{A}}$, the level predicted by its structural characteristics. By the same token, country $B$, although it has a higher absolute level of access than country $A\left(D_{B}>D_{A}\right)$, is underperforming relative to peers with similar structural characteristics $\left(\mathrm{D}_{\mathrm{B}}<\mathrm{STRUCT}_{\mathrm{B}}\right)$.

Pro-finance policies and a favorable environment can push access upward for countries with different structural characteristics, eventually reaching a maximum sustainable level, which defines the Financial Possibility Frontier (FPF) for inclusion. Although the FPF is very difficult to pin down empirically, conceptually it combines the idea of eliminating distortions and frictions that constrain financial activity, while guarding against excesses that may lead to highly disruptive boom-bust cycles. Thus, a third country $\mathrm{C}$ may be exceeding the amount of access and financial depth that is sustainable in the long run and could therefore be building up excessive risk.

\footnotetext{
${ }^{26}$ A similar analysis could be carried out on a financial depth variable such as the ratio of private sector credit to GDP, as shown in the empirical analysis of this section.

27 The graphical treatment here makes the simplifying assumption that this relationship is linear. However, this need not be the case.
} 
The following empirical exercise seeks to identify differences across countries, not on their absolute level of access or depth - the total vertical distance to a point for a given country, for example $\mathrm{D}_{\mathrm{B}}$ - but also each country's "gap" relative to the structural benchmark; for example, the vertical distance between $\mathrm{D}_{\mathrm{B}}$ and $\mathrm{SD}_{\mathrm{B}}$. The gap represents a country's degree of overperformance or underperformance relative to its structural peers.

For the latter purpose, the analysis draws on an empirical approximation of the Structural Access line, as estimated by Feyen, Kibouka, and Sourrouille (2013), whereby panel data regressions were carried out for a number of financial access and depth indicators on a fixed set of structural determinants: (i) the log of GDP per capita and its square (to account for possible nonlinearities), (ii) the log of population to proxy for market size, (iii) the log of population density to proxy for the ease of service provision, (iv) the log of the age dependency ratio to control for demographic trends and corresponding savings behavior, and (v) other fundamental factors (an offshore center dummy, a transition country dummy, and an oil-exporting country dummy) to control for specific country circumstances. The resulting predicted values from the regressions then constitute the benchmark levels for each financial access or depth variable: FA $_{i, t} \mathrm{~B}$, for each country $i$ and in each year $t$ for which data are available.

Therefore, the Gap is constructed as the difference between the actual level of access/depth and the FA and the benchmark FA ${ }^{\mathrm{B}}$ estimated by Feyen, Kibouka, and Sourrouille, with a positive (negative) gap value thus indicating over (under) performance:

$$
G a p_{i t}=F A_{i t}-F A_{i t}^{B}
$$

We concentrate our analysis on the four financial inclusion indicators for which Feyen, Kibouka, and Sourrouille (2013) conducted the benchmarking exercise-Number of bank accounts per 1,000 adults, Number of branches per 100,000 adults, Percent of firms with credit (or a credit line), and Percent of small firms with credit (or a credit line). Note that the first two indicators are drawn from the FAS database and therefore contain some time variation, whereas the latter two are derived from the World Bank Enterprise Surveys, and contain at most two time observations per country.

Comparing the Gaps across countriesthat is, comparing financial inclusion

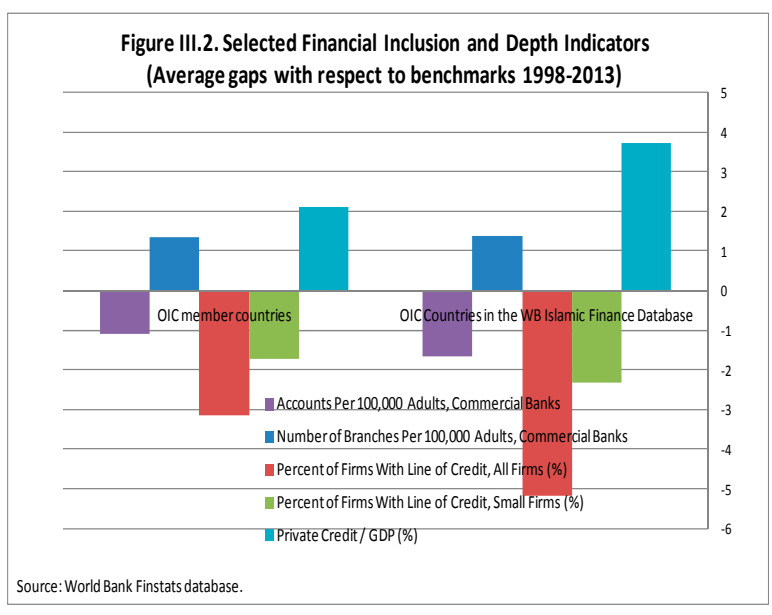
indicators after cleaning out the effect of structural characteristics - shows a rather mixed 
picture for OIC countries and Islamic banking (Figure III.2). On average, OIC countries seem to underperform relative to their structural peers on access to accounts and to firm credit, but slightly overperform in access to branches and depth. The OIC countries with Islamic banking underperform similarly on proliferation of bank branches, but underperform even more on accounts and use of bank credit by firms. Islamic banking OIC countries also appear to overperform even more than other OIC countries on financial depth.

For the most part these differences across groups of countries are not statistically significant, nor is there a significant association between the Gaps in financial inclusion and Islamic banking activity. Table III.3 shows the results of the simple regression equation (4), where the Gap is used in place of the financial inclusion indicators, and GDP per capita is dropped because it is already incorporated in the estimates of the structural benchmark. Not only do all three Islamic banking variables - $I B_{0}, I B_{1}$ and the $W B I B$ dummy - fail to register a significant association with Gap, but the $O I C$ fails as well. That is, once structural factors are accounted for, it becomes less clear that OIC countries as a group are underperforming on financial inclusion.

$$
G A P_{i}=\beta_{0}+\beta_{1} O I C_{i}+\beta_{2}\left(O I C_{i} \cdot I B_{j i}\right)
$$

Furthermore, Table III.3 also incorporates a specification of equation (4) in which the dependent variable is the change in the Gap over time, with similarly weak results. Although the coefficient on the OIC dummy is always positive, suggesting that the two financial inclusion indicators with time variation - number of accounts and branches - have been improving more rapidly (or decreasing less rapidly) than the structural factors, the coefficient is not significant. Likewise, there is little indication that Islamic banking has been associated with changes in financial inclusion above or below levels explained by the structural determinants.

It should be noted that a separate exercise,${ }^{29}$ using Islamic banking measures as shares of the total commercial bank industry, gives only limited evidence of an impact of Islamic banking, and mostly on access to bank branches. However, these results were not robust to different specifications. ${ }^{30}$ Furthermore, financial depth was found to be negatively associated with Islamic banking, although rarely significantly so.

To conclude, this section examined a wide variety of supplier-side and user-side indicators of financial inclusion, comparing OIC countries with the rest of the world, and, within OIC, those countries with active Islamic banking sectors and those without. At first pass, it seemed to be the case that OIC countries are less financially inclusive than the rest of the world, in

\footnotetext{
${ }^{29}$ Results of this exercise are available upon request.

${ }^{30}$ In fact, cross-country regressions that include these Islamic banking share variables yield even weaker results. Furthermore, when the sample is limited to OIC countries, the Gap regressions fail to yield robust results; positive and significant coefficients for Islamic asset and number shares in the pooled regression for access to branches turn negative and significant in the fixed-effects regressions.
} 
part because of religious self-exclusion. It also appeared that Islamic banking might be playing an important role, presumably by reducing religious self-exclusion and therefore creating conditions for greater use of financial services. Once country income per capita was accounted for, however, financial inclusion for OIC countries remained significantly lower, but it was no longer the case that the Islamic banking subgroup outperformed the other OIC countries. Delving further, the regression analysis went beyond simple country classifications to show that indicators of Islamic banking presence and activity within the OIC countries are associated with greater use of bank credit by households and by firms as a means to finance investment; however, there was no significant effect on other indicators of credit use, such as the share of all or small firms using bank credit, or the share of firms identifying lack of access as a binding constraint. Finally, although this analysis had controlled for a key structural variable determining financial inclusion-income per country - there was recognition of a broader set of structural variables that one would need to account for. Drawing on the benchmarking exercise conducted by Feyen, Kibouka, and Sourrouille (2013) on a subset of four financial inclusion indicators, the results weakened even further, with no significant differences between OIC countries and the rest and no significant difference within the group of OIC countries.

Thus, this section showed that the empirical link between Islamic banking and financial inclusion at the macro level remains tentative and relatively weak, in fact mirroring the types of results obtained at the micro level by Demirguc-Kunt, Klapper, and Randall (2013). The weakness in the results may be partly owing to data issues. Although progress was made in incorporating adequate measures of Islamic banking, producing significant results for some of the user-side (non-benchmarked) inclusion indicators, it is clear that wider coverage as well as greater uniformity of definitions of Islamic banking are crucial to uncovering statistically reliable associations, should they exist. Moreover, the analysis on the Gaps in financial inclusion should caution one against attributing differences in inclusion across groups of countries to one single factor, such as whether it is an OIC country. Finally, it is also possible that it is difficult to generalize the experience of Islamic banking so far, and that there may be other, complementary country-specific conditions and/or policies that help to explain why Islamic banking might boost financial inclusion in some countries and not in others. In the next section we explore possible factors associated with the inability of Islamic finance to generate significant gains in inclusion so far, and suggest policies that might help.

\section{POLICIES FOR ENHANCING FINANCIAL INCLUSION}

This section presents Islam's perspective on financial inclusion. It will look first at possible reasons why Islamic finance, in its current form, has not significantly contributed to improving inclusion. In addition, it will highlight the potential of Islamic finance for inclusion. The section will end with recommendations on how to enhance financial access through Islamic banking. 


\section{A. Constraints and Potential for Access to Finance}

As shown in the previous section, the evidence of Islamic finance having had a significant impact on access to date is very weak. There may be several possible reasons why: (i) the observed weakness in financial infrastructure in OIC and ISB countries, which could limit the capacity of Islamic banks to select, monitor, and fund households and SMEs-For example, on strength of legal rights, the performance of OIC countries is well below the average in other, non-MENA regions (Figure IV.1); (ii) innovation in Islamic banking is constrained because the regulatory environment in most OIC and ISB countries is still in its incipient stages (IFC, 2014), which might limit the capacity of Islamic

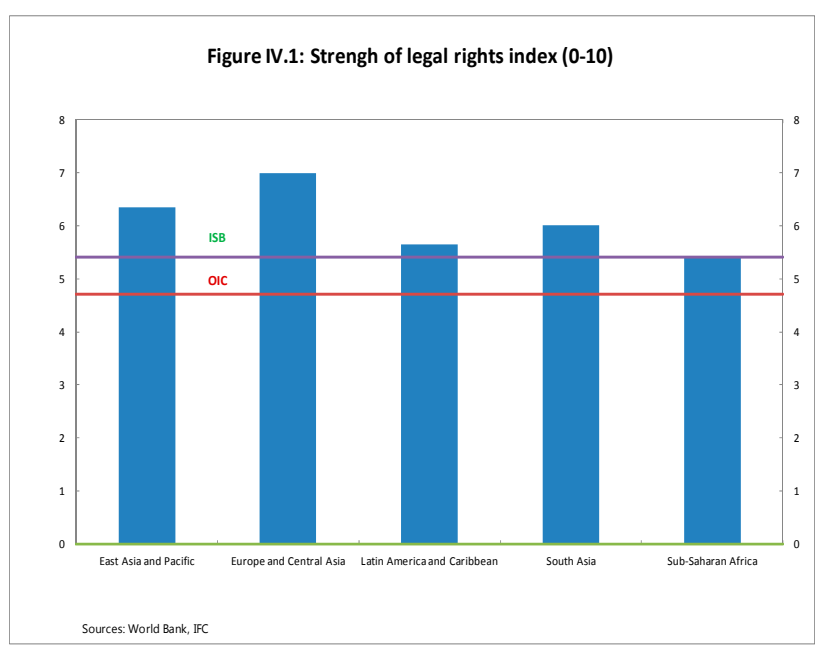
banks to design authorized Islamic products that meet the needs of SMEs and households; (iii) despite its growth, Islamic banking still represents less than 2 percent of banking assets worldwide (UKIFS, 2013), and therefore might need to expand further in order to make a noticeable impact on inclusion; ${ }^{31}$ and (v) Islamic banks face a dearth of qualified talent and are compelled to recruit staff trained in conventional banking, possibly limiting the ability of these institutions to expand the outreach of their services (Jabr 2003).

However, there seems to be potential to develop Islamic finance as a means of improving financial access, particularly in certain countries (IFC, 2014). In Saudi Arabia, for example, 90 percent of SMEs indicate a strong preference for Shari'ah-compliant products. SMEs

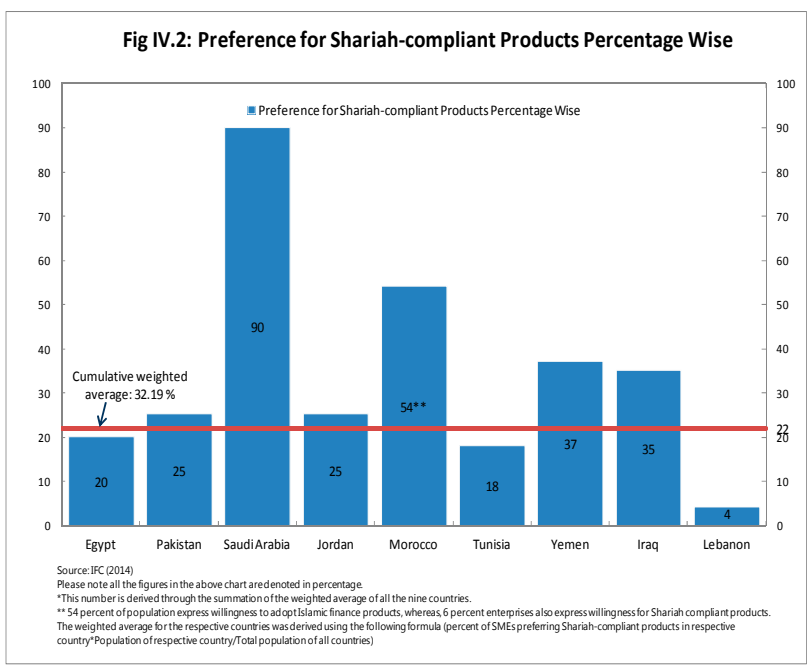
in Morocco and Jordan (54 percent and 45 percent, respectively) also reported a strong interest in Shari'ah-compliant banking services. In general, there is a substantial demand for Islamic banking among the MENA region's SMEs: approximately 35 percent of such businesses express their need for financing by Islamic banks. As mentioned in the Introduction, the Demirguc-Kunt, Klapper, and Randall (2013) study reports that a plurality

\footnotetext{
${ }^{31}$ For example, it is noteworthy, from the survey results on a sample of Muslims in five OIC countries reported in Demirguc-Kunt, Klapper, and Randall (2013), that more than half of respondents were unaware of the existence of Islamic banking services.
} 
of respondents to an interview of 5000 adults in five MENA countries expressed a preference for Shari'ah-compliant products, even though these have higher costs than conventional products.

\section{B. Policies to Foster Access through Islamic Finance}

While most OIC countries have taken measures to improve financial access, there is no comprehensive high level of commitment to reform Islamic banking with the aim of increasing financial inclusion. The array of measures we outline in this paper includes three dimensions of policy that could help Islamic finance enhance financial access: the first is related to the improvement of the current operating model of Islamic banks; the second includes private and public sector initiatives to strengthen the role of Islamic finance in broadening financial access, and the third focuses on reforms of financial infrastructure and regulation that could also apply to conventional finance.

Islamic banks may need to improve their current operating model so as to attract depositors and serve SMEs, which have so far been excluded from the formal financial sector for religious considerations. ${ }^{32}$ One option is to create separate SME business units within Islamic financial institutions, to understand the market dynamics of these firms, and to tailor Islamic financial instruments to their specific needs. There is also a need to better train bank personnel in Shari'ah-compliant instruments and to streamline the execution of Islamic transactions, especially those related to loan applications for SMEs. Islamic banks need to introduce credit evaluation techniques such as behavioral scoring and an early warning system to better price and reduce risk exposure to SMEs, which will help develop equityrelated instruments (musharaka ${ }^{33}$ and mudaraba $^{34}$ ) and ijara $^{35}$ for SMEs. Islamic banks can also explore the potential of private equity (PE) and venture capital (VC), both of which seem well suited to Islamic models of finance. In this regard, Bahrain provides an example of the successful introduction of an Islamic VC bank focused on financing SMEs. The most appropriate way to encourage the development of $\mathrm{PE} / \mathrm{VC}$ is to develop the domestic capital market for easing the exit of $\mathrm{VC}$ banks from the capital of funded firms, to promote business incubators, and to review the legal framework related to intellectual property protection and the security of financial transactions (OECD, 2006).

\footnotetext{
32 The recommendations on improving the Islamic bank operating model are based on an IFC study on Islamic banking and SMEs in MENA (IFC, 2014).

${ }^{33}$ Musharaka is a profit-and-loss sharing partnership and is the most authentic form of Islamic financing. It is a contract of joint partnership where two or more partners provide capital to finance a project, or to own real estate or a movable asset, either on a permanent or diminishing basis (Shahmoradi and others, 2014).

${ }^{34}$ Mudaraba is a PLS contract where one party supplies funding (financier as principal) and the other provides effort and management expertise (mudarib or entrepreneur as agent) with a view to generating a profit (Shahmoradi and others, 2014).

${ }^{35}$ Shahmoradi and others (2014) define Ijara as "a contract of sale of the right to use an asset for a period of time. It is essentially a lease contract, whereby the leaser must own the leased asset for the entire lease period."
} 
On the second policy dimension, private and public sector initiatives can be pursued to enlarge the role of Islamic finance in improving financial access. The development of Islamic microfinance could offer more effective tools for improving financial inclusion than conventional microfinance..$^{36}$ On the funding side, Islamic microfinance companies can mobilize additional resources such as $z a k a t^{37}$ and $w a q f,{ }^{38}$ and on the lending side they mainly use financial instruments that are based on Profit and Loss Sharing (PLS) schemes such as mudarabah and musharaka rather than loans, avoiding the imposition of oppressively high interest rates on poor households and small entrepreneurs. ${ }^{39}$ To help Islamic microfinance improve access, Islamic banks could be allowed to open microfinance branches or to develop a Shar'iah-compliant finance model for microfinance. Qard-al-Hassan ${ }^{40}$ resources should be made available to Islamic microfinance institutions to reduce the burden of high interest charges on their borrowers (Iqbal and Mirakhor, 2013). Zakat funds could be used to cover the default risk of microenterprises and to build capacity and skills (Iqbal and Mirakhor, 2013).

Establishing Islamic equity funds for SMEs could also be a possibly beneficial source of finance, especially for high-risk SMEs that lack access to conventional bank finance and cannot afford the compliance costs associated with listing in capital markets. Developing a Shar'iah-compliant financial market (equity and sukuk), where both the instruments and trading process would be in line with the Shari'ah requirement for transactions (Bacha and Mirakhor, 2013), could help alleviate the finance constraints on SMEs. Encouraging sukuk ${ }^{41}$ issuance is more appropriate than issuing securities for SMEs because sukuk protect shareholders against ownership dilution. Besides, sukuk could also be used to securitize loans granted to microenterprises and SMEs and provide additional funding for this excluded segment of the economy.

Other initiatives that might help to enhance financial inclusion include institutionalization of Islamic redistributive mechanisms such as zakat, sadaqat, qard-al-Hassan and waqf (Mohieldien and others, 2011). The aim of institutionalization is to formalize and standardize operations and to enhance the effectiveness of these instruments for addressing the lack of financial inclusion in Muslim countries. Elgari (2004) suggests increasing the provision of

\footnotetext{
${ }^{36}$ The lack of funding and the high administrative costs make the cost of providing finance exorbitantly high for conventional microfinance (Ahmed, 2002).

${ }^{37}$ Zakat is tax collected from relatively richer Muslims and distributed mainly among poorer Muslims (Gait and Worthington, 2007). There are only eight categories (Asnafs) eligible to receive the accumulative Zakat money.

${ }^{38}$ Waqf is a trust or pious foundation (Hassan and Lewis, 2007).

${ }^{39}$ Kahf (2004) and Ahmed (2003) support the idea of establishing an Islamic microfinance institution funded by zakah, waqf, and sadakat.

${ }^{40}$ Qard-al-Hassan is an interest-free loan that the Qur'an encourages Muslims to make to the needy (Shahmoradi and others, 2014).

${ }^{41}$ Sukuk is a freely tradeable Islamic participation certificate based on the ownership and exchange of an approved asset (Hassan and Lewis, 2007).
} 
redistributive financial services by setting up a nonprofit financial institution funded by waqf that would provide Qard-al-Hassan to poor consumers. Mohieldien and others (2011) propose the establishment of an awqaf fund to provide investment and working capital financing to microenterprises.

Another option worth exploring is the establishment of an Islamic partial credit guarantee scheme (IPCG) or extension of the existing PCG to Islamic banks with the aim of reaching underserved groups such as SMEs and startups, especially at a time when governments are improving credit information and creditor rights (see the experience of Jordan, which recently established a Shari'ah-compliant loan guarantee). Successful IPCGs may consider a coverage ratio closer to international standards (around 30-40 percent), fees could be closely tied to risks, and systematic assessments should be conducted regularly to ensure cost-effectiveness and customer satisfaction (Saadani and others, 2010).

On the third dimension of pro-inclusion policy, there are actions that have been shown to be effective for banking systems in general. Improvement of financial infrastructure is one such action. In particular, credit reporting needs to improve in both depth and coverage, which would require the upgrade of public registries, the introduction of private credit bureaus, the enlarging of credit reporting of utilities and retailers, and the coverage of both personal and commercial credit information (Figure IV.3.). There is also a need to improve credit protection, because, as shown earlier, the region ranks low in the area of credit rights as measured by the legal rights

index. This may require enlarging the pool of assets acceptable as collateral, ${ }^{42}$ adopting collateral regimes, and developing out-of-court enforcement mechanisms.

As shown by our macro-level results as well as those of Love and Martínez Pería (2012) analyzing firm-level data, increased bank competition is associated with gains in financial inclusion on the
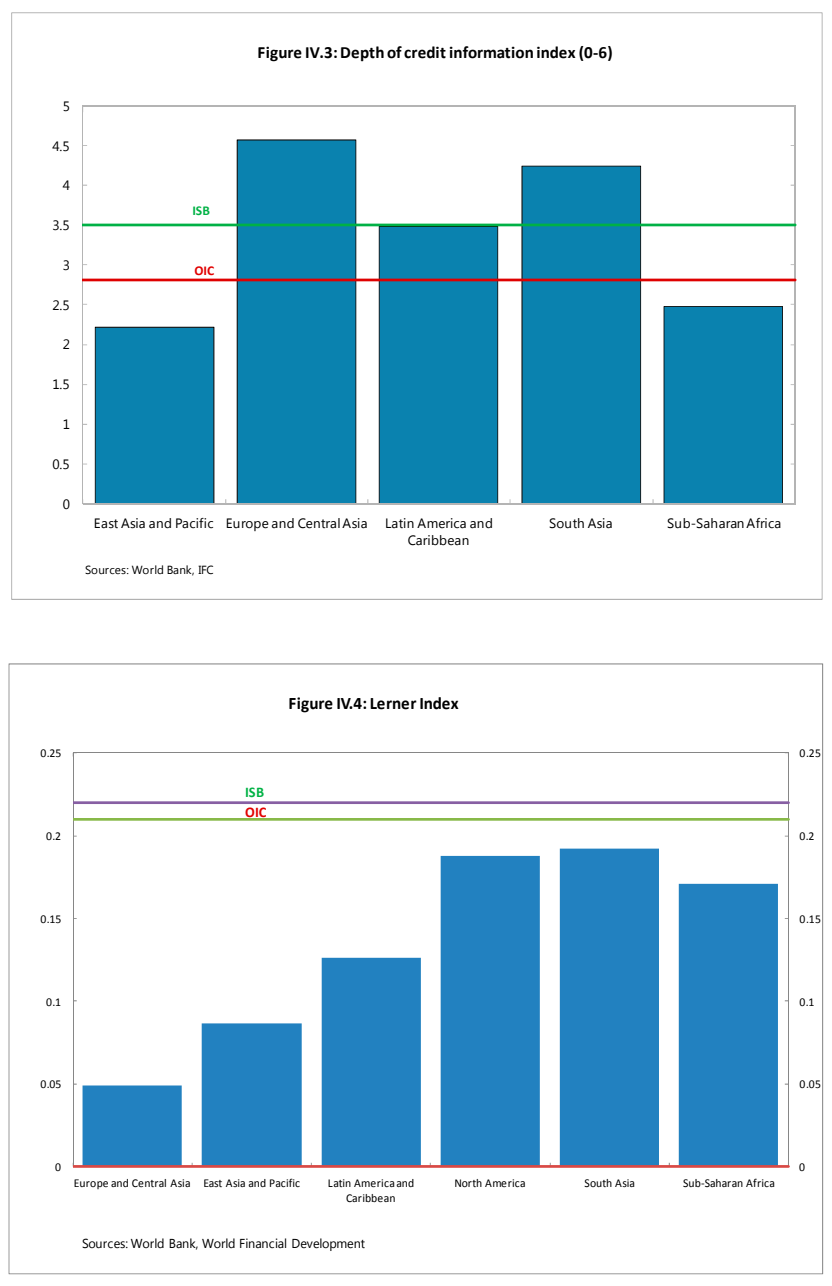

\footnotetext{
${ }^{42}$ For example, Love, Martínez Pería, and Singh (2013) show that the introduction of movable collateral registries has been associated with increased access by firms to bank credit.
} 
credit side. There is ample potential for improvement in this regard in the OIC and Islamic banking countries, both of which tend to display less competition as shown by the Lerner index in Figure IV.4. Increased competition could help to push Islamic and conventional banks to develop business lines beyond large corporations and expand the SME segments of the market. This could be done by easing entry into banking, developing the capital market, and reducing loan concentration though prudential measures.

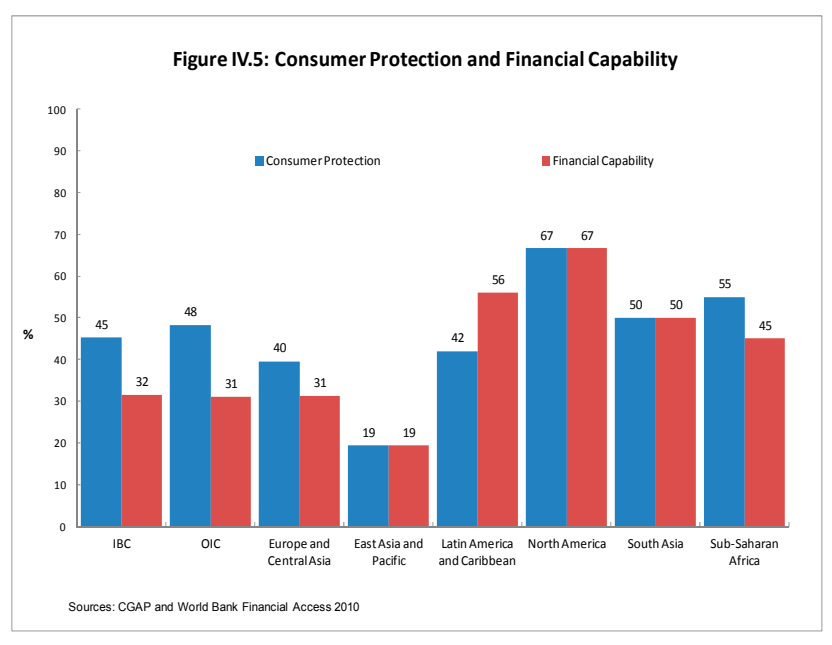

Finally, consumer protection, financial education, and a sound regulatory and supervisory framework for Islamic finance could be helpful in encouraging households and enterprises to use Shari'ah-compliant instruments. Government and regulators also need to support improvements in access, especially through Shari'ah-compliant financial instruments, and consider better access a goal as important as financial stability (Mohieldien and others 2011).

\section{CONCLUDing OBSERVATIONS}

This paper provides the empirical results for a possible link between the presence and activity of Islamic banking and financial inclusion, across a wide array of measures of both. Specifically, we explored the IMF's FAS and the World Bank's Findex and Enterprise Survey to examine the extent to which Islamic banking development is related to trends in supply-side and user-side measures of financial inclusion in Muslim countries. The results present a mixed picture of Islamic banking and financial inclusion. A first pass of the data suggested that, though physical access to financial services has increased more rapidly in OIC countries, it seemed to be the case that OIC countries in recent years are still less financially inclusive than the rest of the world, in part because of religious self-exclusion. On the other hand, the Islamic banking OIC countries seemed to have slightly higher levels of inclusion, suggesting that religious self-exclusion had been mitigated to some extent.

We then conducted two types of tests, one to assess whether the different supplier-side and user-side measures of financial inclusion are correlated with different measures of Islamic banking, and another to assess to what extent this relationship holds once structural determinants of financial inclusion are fully accounted for. We found that after accounting for country income per capita, the lower financial inclusion for OIC countries remained significant, but it was no longer the case that the Islamic banking subgroup outperformed the other OIC countries. Furthermore, we found some evidence that Islamic banking presence and activity were associated with greater inclusion with regard to bank credit by households and by firms as a means to finance investment. Finally, when comparing actual to benchmark levels of four indicators of financial inclusion - that is, the Gaps relative to what would be expected given a country's structural characteristics - we found no significant impact of Islamic banking; nor did we find significant differences between OIC countries and others. 
Thus, we found weak and tentative evidence of Islamic banking's positive impact on some types of inclusion. This weakness in the results may be partially related to data issues, including the limited coverage of Islamic banking indicators and of financial inclusion indicators among the OIC countries. Although the coverage has been steadily increasing, encouraging countries to collect and report FAS data to the IMF, and increasing the frequency of the user-side surveys will deepen the understanding of the relationship between Islamic banking and financial inclusion for researchers and policymakers. The weakness of the empirical link between Islamic banking and financial inclusion may also be owing to additional country-specific characteristics that are not adequately captured by the structural factors, to shortcomings in how Islamic banking has been developing so far, or to deficiencies in the credit environment, which affect the ability of the entire banking system to make progress on inclusion.

Our work proposes several recommendations for enhancing the contribution of Islamic finance to financial inclusion. Specifically, we propose changes to the operating model of Islamic banks that may enhance inclusion: Islamic banks could create separate SME business units and improve the training of bank personnel in Sharia'ah-compliant instruments, while concurrent actions are taken to support the development of PE and VC activity. In addition, the potential development of Islamic microfinance could be explored, as well as the establishment of Islamic equity funds for SMEs and the institutionalization of Islamic redistributive mechanisms. Finally, improving financial infrastructure, introducing more competition in the banking system, improving the quality of credit information, and enhancing the efficiency of the legal system will help promote financial inclusion, regardless of whether the banking industry contains Islamic banks. 
Table II.1

Country Groups

\begin{tabular}{|cc|c|}
\hline \multicolumn{2}{|c|}{ OIC with Islamic Banking } & OIC without Islamic Banking \\
\hline Afghanistan & Mauritania & Benin \\
Albania & Nigeria & Chad \\
Algeria & Oman & Comoros \\
Azerbaijan & Pakistan & Gabon \\
Bahrain & Qatar & Guinea \\
Bangladesh & Saudi Arabia & Guinea-Bissau \\
Brunei & Senegal & Guyana \\
Burkina Faso & Sudan & Kazakhstan \\
Cameroon & Syrian Arab Republic & Kyrgyz Republic \\
Cote d'Ivoire & Tunisia & Libya \\
Djibouti & Turkey & Mali \\
Egypt, Arab Rep. & Uganda & Morocco \\
Gambia, The & United Arab Emirates & Mozambique \\
Indonesia & West Bank \& Gaza & Niger \\
Iran, Islamic Rep. & Yemen, Rep. & Sierra Leone \\
Iraq & & Somalia \\
Jordan & & Suriname \\
Kuwait & & Tajikistan \\
Lebanon & & Togo \\
Malaysia & & Turkmenistan \\
Maldives & & Uzbekistan \\
\hline
\end{tabular}


Table II.2

Summary of indicators

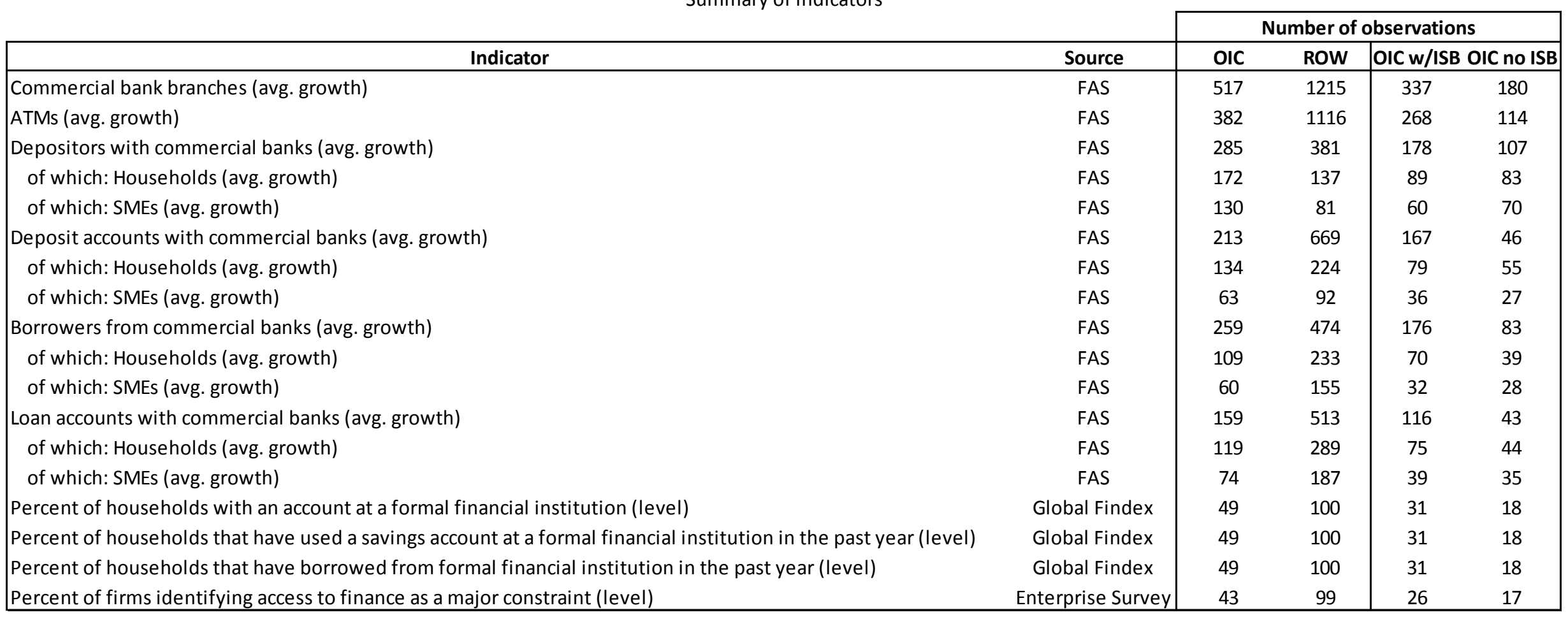




\section{Table II.3}

Mean growth rates and levels for selected variables

\begin{tabular}{|c|c|c|c|c|}
\hline \multirow[b]{2}{*}{ Indicator } & \multicolumn{4}{|c|}{ Mlean growth rates and levels for selected varıables } \\
\hline & OIC & ROW & OIC $w / I S B$ & OIC no ISB \\
\hline Commercial bank branches (avg. growth) & 8.2 & 3.6 & 7.0 & 10.5 \\
\hline ATMs (avg. growth) & 18.3 & 11.3 & 18.4 & 18.0 \\
\hline Depositors with commercial banks (avg. growth) & 10.0 & 9.6 & 9.0 & 11.7 \\
\hline of which: Households (avg. growth) & 11.1 & 9.0 & 9.8 & 12.4 \\
\hline of which: SMEs (avg. growth) & 1.1 & 11.8 & 3.1 & -0.5 \\
\hline Deposit accounts with commercial banks (avg. growth) & 9.0 & 8.1 & 8.0 & 12.4 \\
\hline of which: Households (avg. growth) & 8.6 & 8.7 & 9.6 & 7.2 \\
\hline of which: SMEs (avg. growth) & 15.2 & 11.6 & 14.9 & 15.6 \\
\hline Borrowers from commercial banks (avg. growth) & 11.6 & 9.9 & 9.6 & 15.9 \\
\hline of which: Households (avg. growth) & 2.6 & 10.5 & 9.2 & -9.6 \\
\hline of which: SMEs (avg. growth) & 11.0 & 9.2 & 9.5 & 12.8 \\
\hline Loan accounts with commercial banks (avg. growth) & 9.2 & 8.7 & 7.6 & 13.7 \\
\hline of which: Households (avg. growth) & 2.2 & 9.2 & 8.2 & -7.7 \\
\hline of which: SMEs (avg. growth) & 14.4 & 7.1 & 11.4 & 17.6 \\
\hline Percent of households with an account at a formal financial institution & 26.8 & 55.3 & 31.2 & 19.2 \\
\hline Percent of households that have used a savings account at a formal financial institution in & 9.9 & 22.6 & 11.5 & 7.1 \\
\hline Percent of households that have borrowed from formal financial institution in the past yea & 7.3 & 11.1 & 8.2 & 5.7 \\
\hline Percent of firms identifying access to finance as a major constraint (level) & 37.6 & 25.9 & 3.7 & 39.8 \\
\hline
\end{tabular}




\section{Table II.4}

Summary of Difference in Means Comparisons (Selected Indicators)

\begin{tabular}{|c|c|c|}
\hline \multirow[b]{2}{*}{ Indicator } & \multicolumn{2}{|c|}{ P-values } \\
\hline & OIC vs. ROW & $\begin{array}{l}\text { OIC with ISB vs. } \\
\text { OIC without ISB }\end{array}$ \\
\hline Commercial bank branches (avg. growth) & $0.00 * * *$ & $0.00 * * *$ \\
\hline ATMs (avg. growth) & $0.00 * * *$ & 0.83 \\
\hline Depositors with commercial banks (avg. growth) & 0.81 & 0.16 \\
\hline SME depositors with commercial banks (avg. growth) & $0.07 *$ & 0.68 \\
\hline Deposit accounts with commercial banks (avg. growth) & 0.46 & $.09 *$ \\
\hline Borrowers from commercial banks (avg. growth) & 0.27 & $0.00 * * *$ \\
\hline Loan accounts with commercial banks (avg. growth) & 0.77 & $.07^{*}$ \\
\hline Percent of households with an account at a formal financial institution & $0.00 * * *$ & $.07^{*}$ \\
\hline Percent of households that have used a savings account at a formal financial institu & $0.00 * * *$ & $.1^{*}$ \\
\hline Percent of households that have borrowed from formal financial institution in the & $0.00 * * *$ & 0.19 \\
\hline Percent of firms identifying access to finance as a major constraint & $0.00 * * *$ & 0.55 \\
\hline
\end{tabular}

Significance levels of 10 percent $\left({ }^{*}\right), 5$ percent $\left({ }^{* *}\right)$, and 1 percent $\left({ }^{* * *}\right)$ 


\section{Table II.5}

Differences in Financial Access and Depth between OIC and Other Countries

\begin{tabular}{|c|c|c|c|}
\hline \multicolumn{4}{|c|}{ Coefficient for the OIC Dummy Variable } \\
\hline & \multicolumn{2}{|c|}{ Cross-Country OLS Results } & \multirow{2}{*}{$\begin{array}{c}\text { Panel Data: Fixed Effects } \\
\text { All time observations } \\
\text { included }\end{array}$} \\
\hline Dependent variable: & $\begin{array}{r}\text { Average values, } \\
1998-2013\end{array}$ & $\begin{array}{r}\text { Last } \\
\text { observation } \\
\text { available }\end{array}$ & \\
\hline \multirow[t]{2}{*}{ Accounts } & -395.28 & -407.91 & $-453.23 * * *$ \\
\hline & $(1.61)$ & $(1.57)$ & $(4.73)$ \\
\hline Observations: & 109 & 109 & 790 \\
\hline \multirow[t]{2}{*}{ Branches } & $-12.43 * * *$ & $-12.17 * * *$ & $-11.66 * * *$ \\
\hline & $(4.18)$ & (4.17) & $(12.38)$ \\
\hline Observations: & 174 & 175 & 1,473 \\
\hline \multirow[t]{2}{*}{ Credit to Firms } & $-19.70 * * *$ & $-20.25 * * *$ & $-20.62 * * *$ \\
\hline & $(5.58)$ & $(5.71)$ & $(6.04)$ \\
\hline Observations: & 95 & 95 & 115 \\
\hline \multirow[t]{2}{*}{ Credit to Small Firms } & $-16.95 * * *$ & $-17.25 * * *$ & $-17.63 * * *$ \\
\hline & $(5.06)$ & (5.10) & $(5.46)$ \\
\hline Observations: & 95 & 95 & 115 \\
\hline \multirow[t]{2}{*}{ Private Credit/GDP } & $-28.00 * * *$ & $-35.48 * * *$ & $-26.90 * * *$ \\
\hline & $(4.15)$ & $(4.54)$ & $(14.82)$ \\
\hline Observations: & 177 & 176 & 2,561 \\
\hline
\end{tabular}

This table shows the estimated coefficient, t-statistic (in parentheses), and number of observations corresponding to a regression of each financial access or depth variable on a constant and/or country fixed effects, and the OIC dummy. Significance levels of 10 percent $(*)$, 5 percent $\left({ }^{* *}\right)$, and 1 percent $\left({ }^{* *}\right)$ are also indicated. In the cross-country OLS regressions in the left-hand portion of the table, each dependent variable is evaluated as an average over 1998-2013 or at its latest available observation. 
Table II.6

Differences in Financial Access and Depth between OIC and Other Countries and Within OIC Between Islamic Banking Countries and the Rest

\begin{tabular}{|c|c|c|c|c|c|}
\hline Dependent variable: & $\begin{array}{r}y: \text { Income per } \\
\text { capita } \\
\end{array}$ & OIC & $O I C \times W B I B$ & Observations & $\mathrm{R}^{2}$ \\
\hline Accounts & $\begin{array}{l}44.920 * * * \\
(6.74)\end{array}$ & $\begin{array}{r}-285.00 \\
(0.73)\end{array}$ & $\begin{array}{r}-146.40 \\
(0.34)\end{array}$ & 109 & 0.318 \\
\hline Branches & $\begin{array}{l}0.306 * * * \\
(4.76)\end{array}$ & $\begin{array}{l}-10.15^{* *} \\
(2.48)\end{array}$ & $\begin{array}{r}0.28 \\
(0.06)\end{array}$ & 172 & 0.197 \\
\hline Credit to Firms & $\begin{array}{l}1.301 * * * \\
(4.26)\end{array}$ & $\begin{array}{l}-16.20 * * * \\
(3.70)\end{array}$ & $\begin{array}{r}1.39 \\
(0.25)\end{array}$ & 95 & 0.384 \\
\hline Credit to Small Firms & $\begin{array}{l}1.203 * * * \\
(4.11)\end{array}$ & $\begin{array}{l}-13.69 * * * \\
(3.26)\end{array}$ & $\begin{array}{r}1.69 \\
(0.32)\end{array}$ & 95 & 0.342 \\
\hline \multicolumn{6}{|c|}{$\begin{array}{l}\text { Indicators of Household Use of Financial Services } \\
\text { Share of adults: }\end{array}$} \\
\hline $\begin{array}{l}\text { Borrowing from a formal financial } \\
\text { institution }\end{array}$ & $\begin{array}{l}0.116^{* * *} \\
(4.73)\end{array}$ & $\begin{array}{l}-4.41 * * * \\
(2.94)\end{array}$ & $\begin{array}{r}2.06 \\
(1.21)\end{array}$ & 142 & 0.233 \\
\hline $\begin{array}{l}\text { With an account at a formal financial } \\
\text { institution }\end{array}$ & $\begin{array}{l}1.172 * * * \\
(13.71)\end{array}$ & $\begin{array}{l}-20.49^{* * *} \\
(3.91)\end{array}$ & $\begin{array}{r}1.97 \\
(0.33)\end{array}$ & 142 & 0.652 \\
\hline $\begin{array}{l}\text { Citing religious reasons for not having } \\
\text { an account }\end{array}$ & $\begin{array}{r}0.204 \\
(0.71)\end{array}$ & $\begin{array}{l}4.12 * * * \\
(2.85)\end{array}$ & $\begin{array}{r}2.26 \\
(1.37)\end{array}$ & 122 & 0.226 \\
\hline \multicolumn{6}{|l|}{$\begin{array}{l}\text { Indicators of Firm Use of Financial Services } \\
\text { Share of firms: }\end{array}$} \\
\hline Using banks to finance investment & $\begin{array}{l}0.541 * * \\
(3.32)\end{array}$ & $\begin{array}{l}-11.50 * * * \\
(3.11)\end{array}$ & $\begin{array}{r}3.63 \\
(0.83)\end{array}$ & 137 & 0.200 \\
\hline Using banks to finance working capital & $\begin{array}{l}0.453 * * \\
(2.45)\end{array}$ & $\begin{array}{l}-7.87^{*} \\
(1.87)\end{array}$ & $\begin{array}{r}-2.54 \\
(0.51)\end{array}$ & 137 & 0.139 \\
\hline $\begin{array}{l}\text { Identifying acces to finance as a major } \\
\text { constraint }\end{array}$ & $\begin{array}{l}-0.634^{* * *} \\
(3.39)\end{array}$ & $\begin{array}{l}10.55^{* *} \\
(2.49)\end{array}$ & $\begin{array}{r}-4.34 \\
(0.85)\end{array}$ & 136 & 0.167 \\
\hline \multicolumn{6}{|l|}{ Percentage of: } \\
\hline Investment financed by banks & $\begin{array}{l}0.347^{* * *} \\
(3.05)\end{array}$ & $\begin{array}{l}-7.02 * * * \\
(2.72)\end{array}$ & $\begin{array}{r}4.10 \\
(1.34)\end{array}$ & 137 & 0.150 \\
\hline Working capital financed by banks & $\begin{array}{l}0.165 * \\
(1.94)\end{array}$ & $\begin{array}{l}-3.33 * \\
(1.72)\end{array}$ & $\begin{array}{r}-0.98 \\
(0.43)\end{array}$ & 137 & 0.107 \\
\hline
\end{tabular}

This table shows the estimated coefficients, t-statistic (in parentheses), and number of observations corresponding to a cross-country OLS regression of each financial inclusion variable on a constant, an OIC dummy variable as well as its interaction with $W B I B$, a dummy variable indicating whether the country is classified as an Islamic Banking country. Significance levels of 10 percent $(*), 5$ percent $(* *)$, and 1 percent $(* * *)$ are also indicated. For the four first financial inclusion variables shown (Accounts, Branches, Credit to Firms and Credit to Small Firms), the latest available observation is taken. For all other financial inclusion variables, there is a single observation available. 
Table III.1

Cross-Country OLS Estimation of the Effect of Islamic Bank Presence and Penetration on Financial Inclusion Indicators

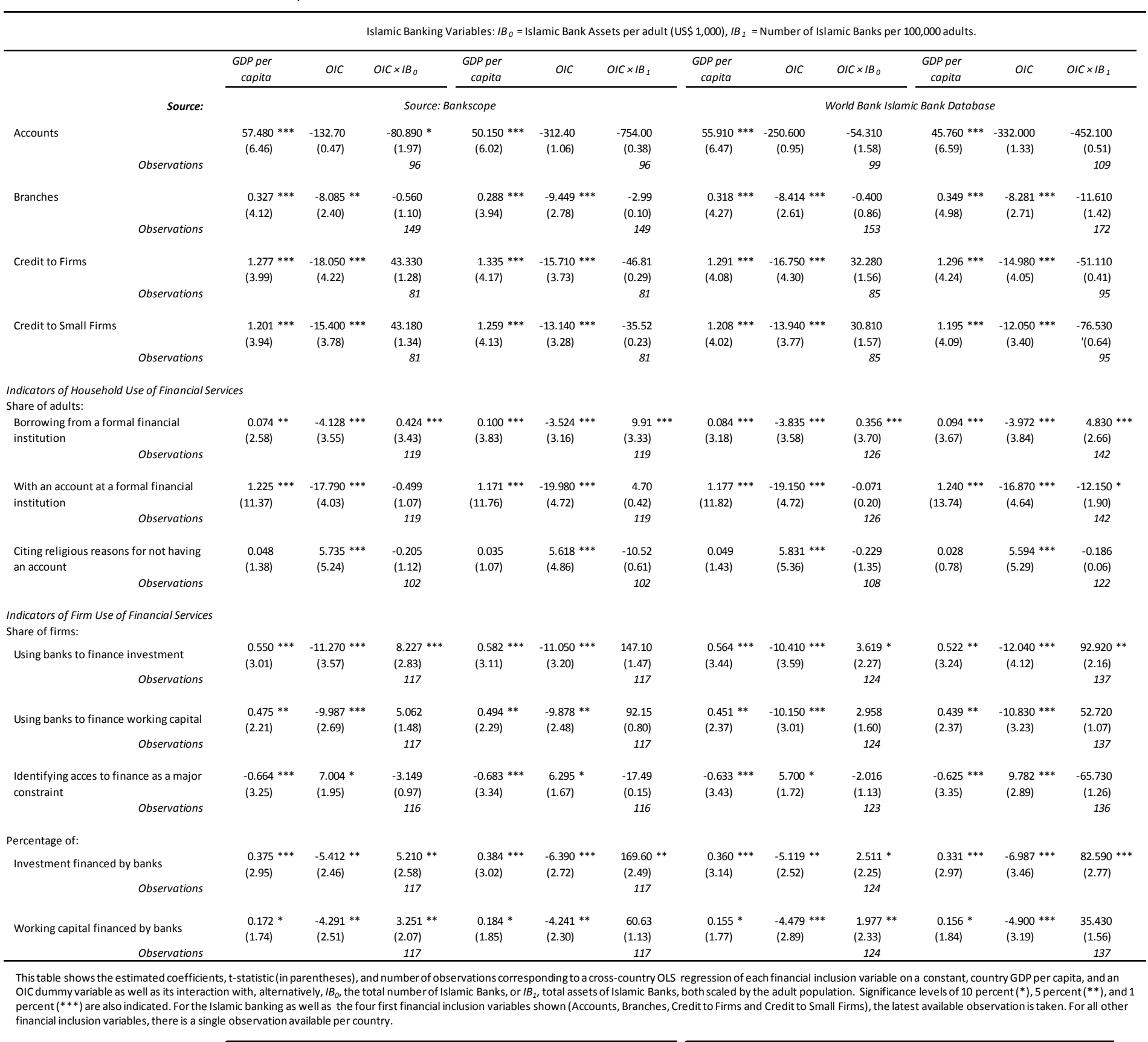


Table III.2A

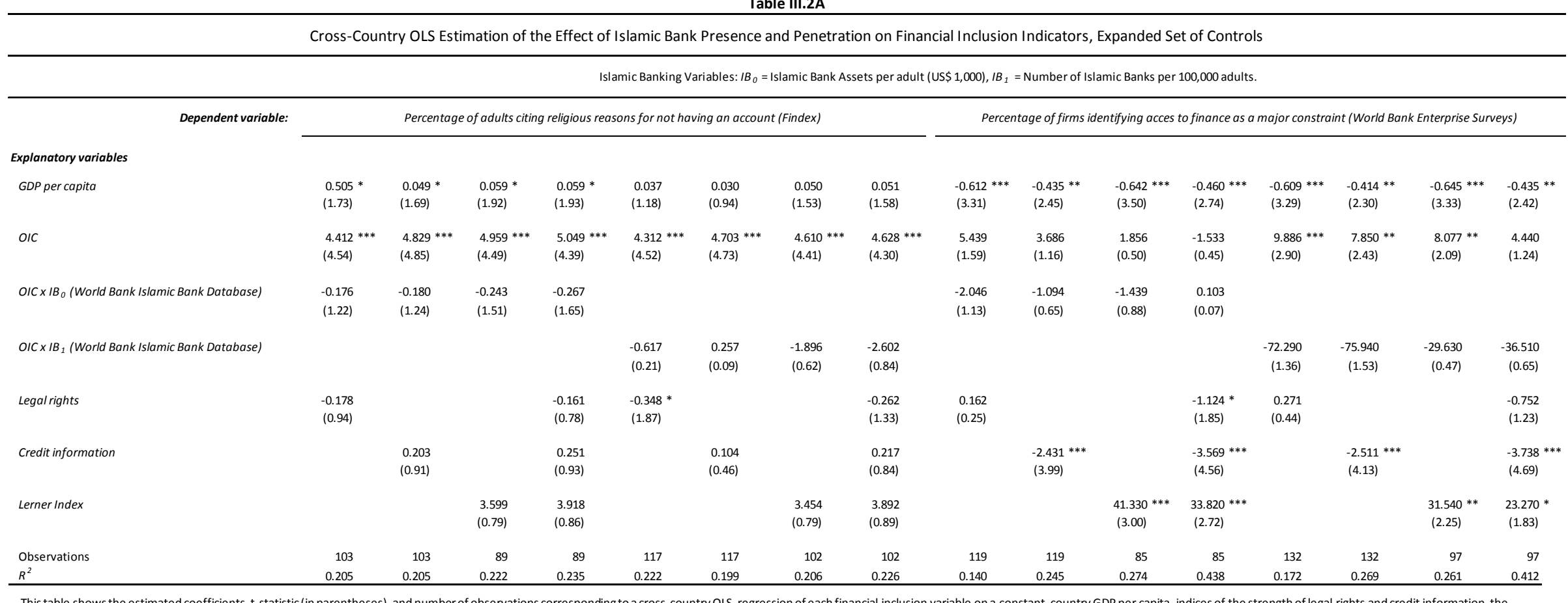

This table shows the estimated coefficients, $t$ - -statistic (in parentheses), and number of observations corresponding to a cross-country OLS regression of each financial inclusion variable on a constant, country GDP per capita, indices of the strength of legal rights and credit information, the indicated. For the Islamic banking variables, the latest available observation is taken. 
Table III.2B

Cross-Country OLS Estimation of the Effect of Islamic Bank Presence and Penetration on Financial Inclusion Indicators, Expanded Set of Controls Islamic Banking Variables: IB $B_{0}=$ Islamic Bank Assets per adult (US\$ 1,000), IB $B_{1}=$ Number of Islamic Banks per 100,000 adults.

\begin{tabular}{|c|c|c|c|c|c|c|c|c|c|c|c|c|c|c|c|c|}
\hline Explanatory variables & \multicolumn{8}{|c|}{ Accounts per thousand adults (Financial Access Survey) } & \multicolumn{8}{|c|}{ Number of branches per 100,000 adults (Financial Access Survey) } \\
\hline GDP per capita & $\begin{array}{l}55.280 * * * \\
(6.42)\end{array}$ & $\begin{array}{l}52.480 \text { *** } \\
(5.98)\end{array}$ & $\begin{array}{l}51.150 * * * \\
(4.93)\end{array}$ & $\begin{array}{l}49.320 * * * \\
(4.75)\end{array}$ & $\begin{array}{l}44.830 * * * \\
(6.44)\end{array}$ & $\begin{array}{l}42.370 * * * \\
(6.00)\end{array}$ & $\begin{array}{l}44.600 \text { *** } \\
(5.30)\end{array}$ & $\begin{array}{l}41.750 \text { *** } \\
(4.89)\end{array}$ & $\begin{array}{l}0.323 * * * \\
(4.30)\end{array}$ & $\begin{array}{l}0.301 \text { *** } \\
(4.00)\end{array}$ & $\begin{array}{l}0.268 * * * \\
(3.12)\end{array}$ & $\begin{array}{l}0.277^{* * *} \\
(3.24)\end{array}$ & $\begin{array}{l}0.359 * * * \\
(5.02)\end{array}$ & $\begin{array}{l}0.333 * * * \\
(4.68)\end{array}$ & $\begin{array}{l}0.320 * * * \\
(3.87)\end{array}$ & $\begin{array}{l}0.334 * * * \\
(3.97)\end{array}$ \\
\hline OIC & $\begin{array}{l}-164.3 \\
(0.61)\end{array}$ & $\begin{array}{l}-263.3 \\
(1.01)\end{array}$ & $\begin{array}{l}-347.7 \\
(1.04)\end{array}$ & $\begin{array}{l}-269.0 \\
(0.78)\end{array}$ & $\begin{array}{l}-255.8 \\
(1.00)\end{array}$ & $\begin{array}{l}-331.7 \\
(1.35)\end{array}$ & $\begin{array}{l}-324.0 \\
(1.01)\end{array}$ & $\begin{array}{l}-259.9 \\
(0.80)\end{array}$ & $\begin{array}{l}-8.902 * * * \\
(2.69)\end{array}$ & $\begin{array}{l}-7.943 \text { ** } \\
(2.46)\end{array}$ & $\begin{array}{l}-7.348 * \\
(1.74)\end{array}$ & $\begin{array}{l}-7.553 * \\
(1.77)\end{array}$ & $\begin{array}{l}-8.729 * * * \\
(2.80)\end{array}$ & $\begin{array}{l}-7.872 \text { ** } \\
(2.57)\end{array}$ & $\begin{array}{l}-7.777 * * \\
(1.99)\end{array}$ & $\begin{array}{l}-7.762 * \\
(1.95)\end{array}$ \\
\hline OIC $\times 1 B_{0}$ (World Bank Islamic Bank Database) & $\begin{array}{r}-54.620 \\
(1.60)\end{array}$ & $\begin{array}{r}-48.210 \\
(1.41)\end{array}$ & $\begin{array}{r}-53.790 \\
(1.27)\end{array}$ & $\begin{array}{r}-54.540 \\
(1.30)\end{array}$ & & & & & $\begin{array}{l}-0.419 \\
(0.90)\end{array}$ & $\begin{array}{l}-0.402 \\
(0.87)\end{array}$ & $\begin{array}{l}-0.289 \\
(0.51)\end{array}$ & $\begin{array}{l}-0.444 \\
(0.78)\end{array}$ & & & & \\
\hline OIC $\times \mid B_{1}$ (World Bank Islamic Bank Database) & & & & & $\begin{array}{l}-393.6 \\
(0.45)\end{array}$ & $\begin{array}{l}-265.8 \\
(0.30)\end{array}$ & $\begin{array}{r}-1,901.6 \\
(1.16)\end{array}$ & $\begin{array}{r}-1,649.6 \\
(1.01)\end{array}$ & & & & & $\begin{array}{r}-12.55 \\
(1.52)\end{array}$ & $\begin{array}{l}-11.26 \\
(1.38)\end{array}$ & $\begin{array}{l}-13.61 \\
(1.28)\end{array}$ & $\begin{array}{l}-16.35 \\
(1.52)\end{array}$ \\
\hline Legal rights & $\begin{array}{l}63.09 \\
(1.31)\end{array}$ & & & $\begin{array}{l}81.65 \\
(1.38)\end{array}$ & $\begin{array}{l}56.55 \\
(1.25)\end{array}$ & & & $\begin{array}{l}67.64 \\
(1.21)\end{array}$ & $\begin{array}{l}-0.392 \\
(0.67)\end{array}$ & & & $\begin{array}{r}-0.899 \\
(1.24)\end{array}$ & $\begin{array}{l}-0.419 \\
(0.74)\end{array}$ & & & $\begin{array}{l}-0.872 \\
(1.25)\end{array}$ \\
\hline Credit information & & $\begin{array}{l}82.20 * \\
(1.74)\end{array}$ & & $\begin{array}{l}86.19 \\
(1.16)\end{array}$ & & $\begin{array}{l}88.85 * \\
(1.96)\end{array}$ & & $\begin{array}{l}87.03 \\
(1.27)\end{array}$ & & $\begin{array}{l}0.854 \\
(1.45)\end{array}$ & & $\begin{array}{l}1.391 \\
(1.48)\end{array}$ & & $\begin{array}{l}0.697 \\
(1.19)\end{array}$ & & $\begin{array}{l}1.032 \\
(1.16)\end{array}$ \\
\hline Lerner Index & & & $\begin{array}{l}122.1 \\
(0.10)\end{array}$ & $\begin{array}{l}502.0 \\
(0.42)\end{array}$ & & & $\begin{array}{l}-10.80 \\
(0.01)\end{array}$ & $\begin{array}{r}217.50 \\
(0.20)\end{array}$ & & & $\begin{array}{r}-14.440 \\
(0.97)\end{array}$ & $\begin{array}{r}-11.530 \\
(0.77)\end{array}$ & & & $\begin{array}{l}-6.018 \\
(0.42)\end{array}$ & $\begin{array}{l}-4.682 \\
(0.32)\end{array}$ \\
\hline $\begin{array}{l}\text { Observations } \\
R^{2}\end{array}$ & $\begin{array}{r}99 \\
0.339\end{array}$ & $\begin{array}{r}99 \\
0.348\end{array}$ & $\begin{array}{r}74 \\
0.296\end{array}$ & $\begin{array}{r}74 \\
0.329\end{array}$ & $\begin{array}{r}109 \\
0.329\end{array}$ & $\begin{array}{r}109 \\
0.343\end{array}$ & $\begin{array}{r}82 \\
0.306\end{array}$ & $\begin{array}{r}82 \\
0.333\end{array}$ & $\begin{array}{r}153 \\
0.180\end{array}$ & $\begin{array}{r}153 \\
0.190\end{array}$ & $\begin{array}{r}110 \\
0.162\end{array}$ & $\begin{array}{r}110 \\
0.189\end{array}$ & $\begin{array}{r}172 \\
0.209\end{array}$ & $\begin{array}{r}172 \\
0.213\end{array}$ & $\begin{array}{r}127 \\
0.192\end{array}$ & $\begin{array}{r}127 \\
0.210\end{array}$ \\
\hline
\end{tabular}

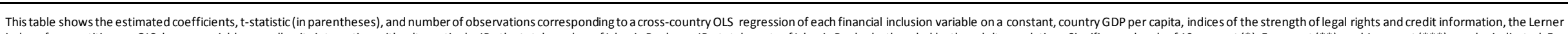

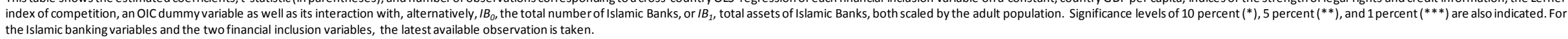


Table III.2C

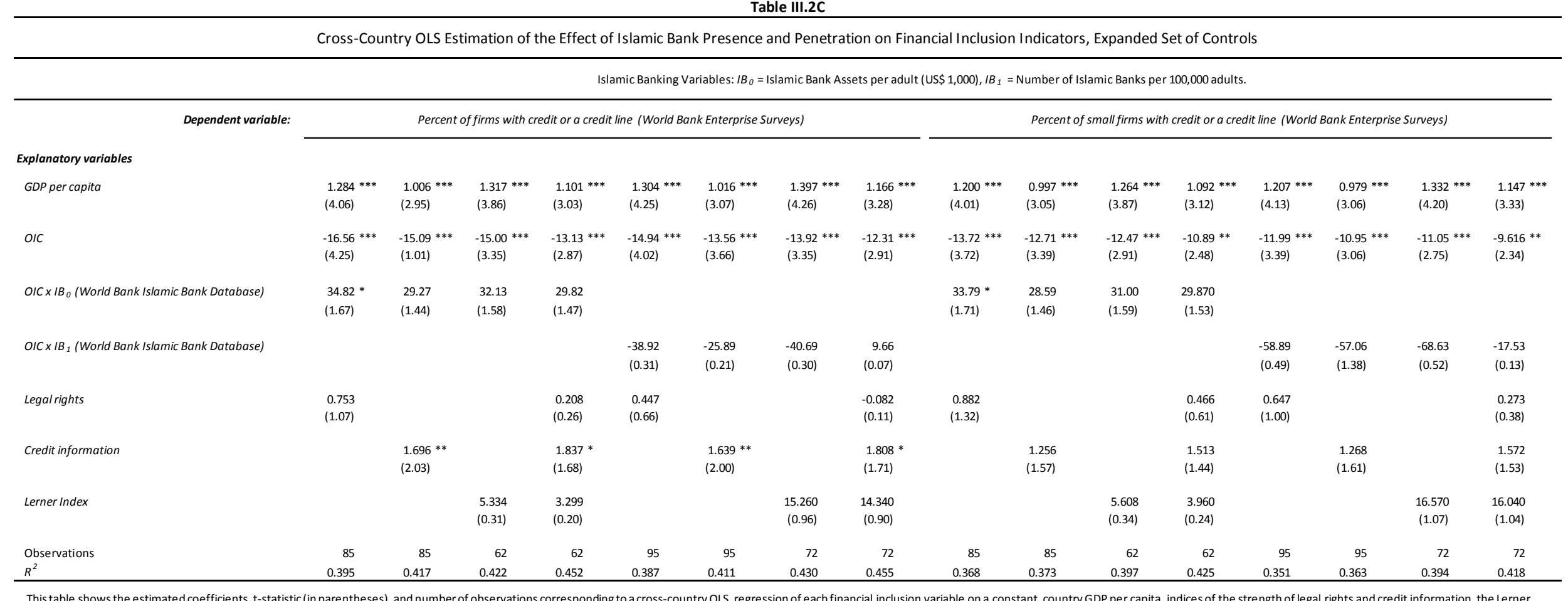

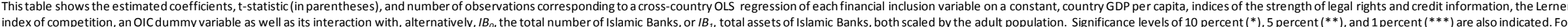
the Islamic banking variables as well as the two financial inclusion variables, the latest available observation is taken. 
Table III.2D



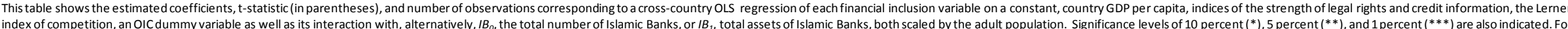
the Islamic banking variables as well as the two financial inclusion variables, the latest available observation is taken. 
Table III.2E

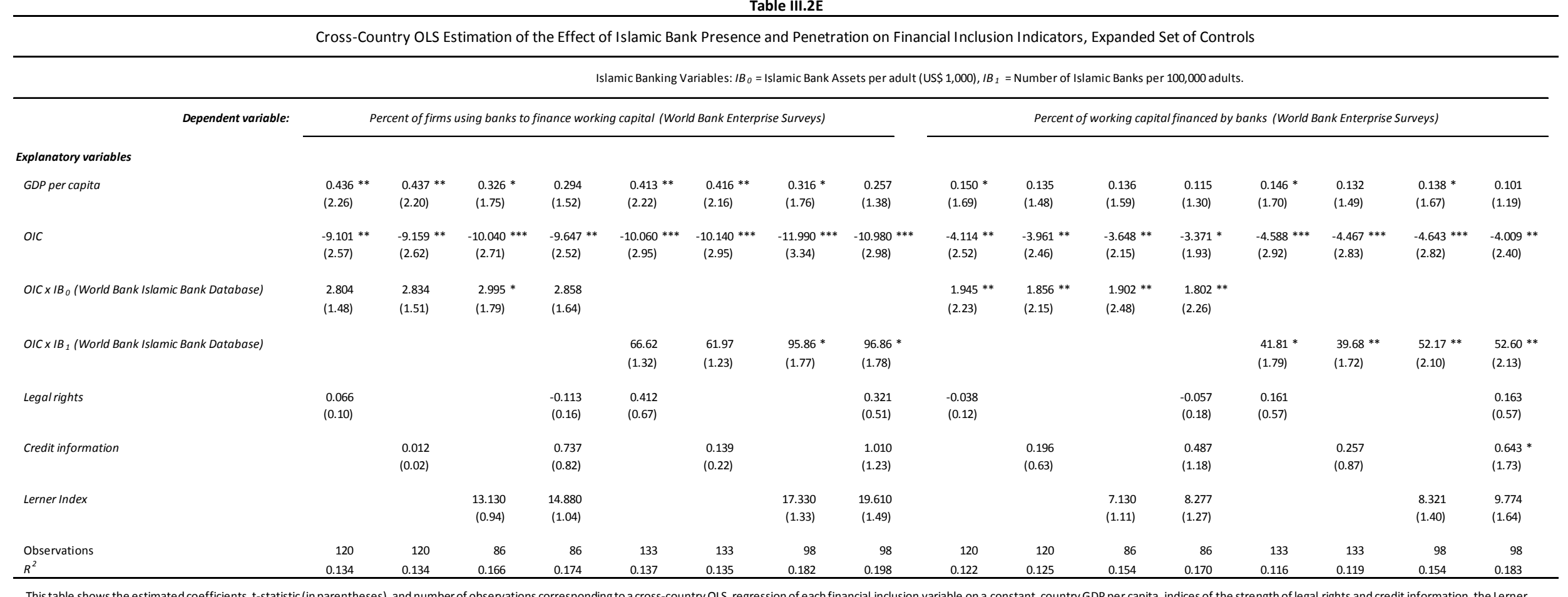

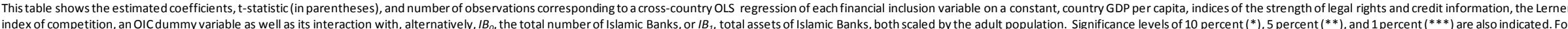
the Islamic banking variables as well as the two financial inclusion variables, the latest available observation is taken. 
Table III.2F

\begin{tabular}{|c|c|c|c|c|c|c|c|c|c|c|c|c|c|c|c|c|}
\hline \multicolumn{17}{|c|}{ oss-Country OLS Estimation of the Effect of Islamic Bank Presence and Penetration on Financial Inclusion Indicators, Expanded Set of Controls } \\
\hline \multirow[b]{2}{*}{ Dependent variable: } & \multicolumn{16}{|c|}{ Islamic Banking Variables: $\mathbb{B}_{0}=$ = Islamic Bank Assets per adult (US\$ 1,000), $B_{1}=$ = Number of Islamic Banks per 100,000 adults. } \\
\hline & \multicolumn{8}{|c|}{ Share of adults who have borrowed from a bank, credit union, or microfinance institution (Findex) } & \multicolumn{8}{|c|}{ Share of adults who have an account at a financial institution or post office (Findex) } \\
\hline GDP per capita & $\begin{array}{l}0.079 * * * \\
(3.09)\end{array}$ & $\begin{array}{l}0.079 * * * \\
(3.06)\end{array}$ & $\begin{array}{l}0.0811^{* * *} \\
(3.00)\end{array}$ & $\begin{array}{l}0.073 * * * \\
(2.76)\end{array}$ & $\begin{array}{l}0.085 * * * \\
(3.35)\end{array}$ & $\begin{array}{l}0.089 * * * \\
(2.16)\end{array}$ & $\begin{array}{l}0.093 * * * \\
(3.51)\end{array}$ & $\begin{array}{l}0.080 * * * \\
(3.04)\end{array}$ & $\begin{array}{l}1.148^{* * *} \\
(11.55)\end{array}$ & $\begin{array}{l}1.147 \text { *** } \\
(11.43)\end{array}$ & $\begin{array}{l}1.1111^{* * *} \\
(10.43)\end{array}$ & $\begin{array}{l}1.076 \text { *** } \\
(10.41)\end{array}$ & $\begin{array}{l}1.197 \text { *** } \\
(13.09)\end{array}$ & $\begin{array}{l}1.209 * * * \\
(13.29)\end{array}$ & $\begin{array}{l}1.181^{* * *} \\
(12.27)\end{array}$ & $\begin{array}{l}1.129 * * * \\
(11.88)\end{array}$ \\
\hline oIC & $\begin{array}{l}-3.192 * * * \\
(2.93)\end{array}$ & $\begin{array}{l}-3.065 * * * \\
(2.76)\end{array}$ & $\begin{array}{l}-3.642 * * * \\
(2.94)\end{array}$ & $\begin{array}{l}-2.867 * * \\
(2.31)\end{array}$ & $\begin{array}{l}-3.392 * * * \\
(3.24)\end{array}$ & $\begin{array}{l}-3.277 * * * \\
(3.04)\end{array}$ & $\begin{array}{l}-3.394 * * * \\
(3.33)\end{array}$ & $\begin{array}{l}-3.302 * * * \\
(2.78)\end{array}$ & $\begin{array}{l}-16.03 * * * \\
(3.79)\end{array}$ & $\begin{array}{l}-15.55 * * * \\
(3.59)\end{array}$ & $\begin{array}{l}-18.58^{* * *} \\
(3.79)\end{array}$ & $\begin{array}{l}-15.18 * * * \\
(3.13)\end{array}$ & $\begin{array}{l}-14.29 * * * \\
(3.79)\end{array}$ & $\begin{array}{l}-13.42 * * * \\
(3.48)\end{array}$ & $\begin{array}{l}-16.54 * * * \\
(3.83)\end{array}$ & $\begin{array}{l}-13.78 * * * \\
(3.21)\end{array}$ \\
\hline OIC $\times 1 B_{0}$ (World Bank Islamic Bank Database) & $\begin{array}{l}0.382 * * * \\
(4.07)\end{array}$ & $\begin{array}{l}0.347 * * * \\
(3.71)\end{array}$ & $\begin{array}{l}0.327 * * * \\
(3.23)\end{array}$ & $\begin{array}{l}0.350 * * * \\
(3.53)\end{array}$ & & & & $\begin{array}{l}4.784 * * \\
(2.53)\end{array}$ & $\begin{array}{l}0.040 \\
(0.11)\end{array}$ & $\begin{array}{l}-0.124 \\
(0.34)\end{array}$ & $\begin{array}{l}0.028 \\
(0.07)\end{array}$ & $\begin{array}{l}0.134 \\
(0.34)\end{array}$ & & & & \\
\hline OIC $\times \mid B_{1}$ (World Bank Islamic Bank Database) & & & & & $\begin{array}{l}5.535 * * * \\
(3.08)\end{array}$ & $\begin{array}{l}4.768 * * * \\
(2.68)\end{array}$ & $\begin{array}{l}4.042 * * \\
(2.13)\end{array}$ & & & & & & $\begin{array}{l}-9.319 \\
(1.44)\end{array}$ & $\begin{array}{c}-12.430 * \\
(1.95)\end{array}$ & $\begin{array}{r}-11.340 \\
(1.64)\end{array}$ & $\begin{array}{l}-8.424 \\
(1.23)\end{array}$ \\
\hline Legal rights & $\begin{array}{l}0.481 * * \\
(2.33)\end{array}$ & & & $\begin{array}{l}0.466 * * \\
(2.15)\end{array}$ & $\begin{array}{l}0.456 \text { ** } \\
(2.30)\end{array}$ & & & $\begin{array}{l}0.450 * * \\
(2.15)\end{array}$ & $\begin{array}{l}2.246 * * * \\
(2.80)\end{array}$ & & & $\begin{array}{l}2.080^{* *} \\
(2.46)\end{array}$ & $\begin{array}{l}1.865 * * * \\
(2.61)\end{array}$ & & & $\begin{array}{l}1.764 * * \\
(2.34)\end{array}$ \\
\hline Credit information & & $\begin{array}{l}0.521 * * \\
(2.10)\end{array}$ & & $\begin{array}{l}0.438 \\
(1.54)\end{array}$ & & $\begin{array}{l}0.456 * \\
(1.85)\end{array}$ & & $\begin{array}{r}0.374 \\
(1.34)\end{array}$ & & $\begin{array}{l}2.335 * * \\
(2.41)\end{array}$ & & $\begin{array}{l}1.877{ }^{*} \\
(1.68)\end{array}$ & & $\begin{array}{l}2.204 * * \\
(2.49)\end{array}$ & & $\begin{array}{l}1.818 * \\
(1.80)\end{array}$ \\
\hline Lerner Index & & & $\begin{array}{r}3.186 \\
(0.69)\end{array}$ & $\begin{array}{r}4.007 \\
(0.88)\end{array}$ & & & $\begin{array}{r}5.849 \\
(1.30)\end{array}$ & $\begin{array}{r}6.715 \\
(1.51)\end{array}$ & & & $\begin{array}{r}-16.660 \\
(0.91)\end{array}$ & $\begin{array}{r}-13.080 \\
(0.74)\end{array}$ & & & $\begin{array}{l}-5.035 \\
(0.31)\end{array}$ & $\begin{array}{r}-1.211 \\
(0.08)\end{array}$ \\
\hline $\begin{array}{l}\text { Observations } \\
R^{2}\end{array}$ & $\begin{array}{r}121 \\
0.314\end{array}$ & $\begin{array}{r}121 \\
0.308\end{array}$ & $\begin{array}{r}107 \\
0.269\end{array}$ & $\begin{array}{r}107 \\
0.321\end{array}$ & $\begin{array}{r}137 \\
0.295\end{array}$ & $\begin{array}{r}137 \\
0.285\end{array}$ & $\begin{array}{r}122 \\
0.258\end{array}$ & $\begin{array}{r}122 \\
0.300\end{array}$ & $\begin{array}{r}121 \\
0.643\end{array}$ & $\begin{array}{r}121 \\
0.637\end{array}$ & $\begin{array}{r}107 \\
0.610\end{array}$ & $\begin{array}{r}107 \\
0.645\end{array}$ & $\begin{array}{r}137 \\
0.673\end{array}$ & $\begin{array}{r}137 \\
0.671\end{array}$ & $\begin{array}{r}122 \\
0.645\end{array}$ & $\begin{array}{r}122 \\
0.671\end{array}$ \\
\hline
\end{tabular}

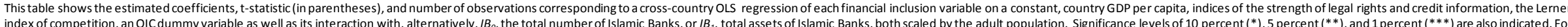
the Islamic banking variables, the latest available observation is taken. 
Table III.3

Cross-Country OLS Estimation of the Effect of Islamic Banking on Gaps Between Financial Inclusion Indicators and Their Structural Benchmarks

\begin{tabular}{|c|c|c|c|c|c|c|c|c|c|c|}
\hline \multirow[b]{2}{*}{ Dependent variable: } & \multicolumn{10}{|c|}{$\begin{array}{l}\text { Islamic Banking Variables: } I B_{0}=\text { Islamic Bank Assets per adult (US\$1,000), } I B_{1}=\text { Number of Islamic Banks per 100,000 adults, WBIB = dummy } \\
\text { variable for classification as an Islamic Banking country }\end{array}$} \\
\hline & OIC & $O I C \times I B_{0}$ & OIC & $O I C \times I B_{1}$ & OIC & $O I C \times I B_{0}$ & OIC & $O I C \times I B_{1}$ & OIC & $\begin{array}{l}O I C x \\
W B I B\end{array}$ \\
\hline Source: & \multicolumn{4}{|c|}{ Bankscope } & \multicolumn{6}{|c|}{ World Bank Islamic Bank Database } \\
\hline \multicolumn{11}{|l|}{$\begin{array}{r}\text { Gaps with respect to structural } \\
\text { benchmarks }\end{array}$} \\
\hline Accounts & $\begin{array}{r}-118.00 \\
(0.46)\end{array}$ & $\begin{array}{l}-35.83 \\
(1.07)\end{array}$ & $\begin{array}{r}-182.50 \\
(0.68)\end{array}$ & $\begin{array}{r}-628.00 \\
(0.36)\end{array}$ & $\begin{array}{r}-192.00 \\
(0.80)\end{array}$ & $\begin{array}{l}-17.53 \\
(0.62)\end{array}$ & $\begin{array}{r}-150.50 \\
(0.67)\end{array}$ & $\begin{array}{r}-515.10 \\
(0.67)\end{array}$ & $\begin{array}{r}5.363 \\
(0.02)\end{array}$ & $\begin{array}{r}-304.4 \\
(0.77)\end{array}$ \\
\hline Observations & & 95 & & 95 & & 98 & & 108 & & 108 \\
\hline Branches & $\begin{array}{l}-0.038 \\
(0.01)\end{array}$ & $\begin{array}{l}-0.060 \\
(0.14)\end{array}$ & $\begin{array}{r}0.137 \\
(0.04)\end{array}$ & $\begin{array}{l}-6.841 \\
(0.27)\end{array}$ & $\begin{array}{l}-0.368 \\
(0.13)\end{array}$ & $\begin{array}{l}-0.035 \\
(0.09)\end{array}$ & $\begin{array}{l}-0.603 \\
(0.23)\end{array}$ & $\begin{array}{l}-1.880 \\
(0.28)\end{array}$ & $\begin{array}{l}-0.178 \\
(0.05)\end{array}$ & $\begin{array}{r}-1.082 \\
(0.25)\end{array}$ \\
\hline Observations & & 148 & & 148 & & 151 & & 171 & & 171 \\
\hline \multirow[t]{2}{*}{ Credit to Firms } & $\begin{array}{r}-3.341 \\
(0.79)\end{array}$ & $\begin{array}{r}3.594 \\
(0.10)\end{array}$ & $\begin{array}{r}-1.884 \\
(0.45)\end{array}$ & $\begin{array}{r}-168.40 \\
(1.03)\end{array}$ & $\begin{array}{r}-2.232 \\
(0.59)\end{array}$ & $\begin{array}{r}9.485 \\
(0.45)\end{array}$ & $\begin{array}{r}-1.402 \\
(0.40)\end{array}$ & $\begin{array}{r}-116.80 \\
(0.95)\end{array}$ & $\begin{array}{l}-0.780 \\
(0.19)\end{array}$ & $\begin{array}{r}-3.986 \\
(0.73)\end{array}$ \\
\hline & & 81 & & 81 & & 85 & & 95 & & 95 \\
\hline Credit to Small Firms & $\begin{array}{l}-2.556 \\
(0.65)\end{array}$ & $\begin{array}{r}15.050 \\
(0.47)\end{array}$ & $\begin{array}{l}-0.613 \\
(0.16)\end{array}$ & $\begin{array}{r}-170.30 \\
(1.12)\end{array}$ & $\begin{array}{l}-0.698 \\
(0.20)\end{array}$ & $\begin{array}{r}13.730 \\
(0.71)\end{array}$ & $\begin{array}{r}0.337 \\
(0.10)\end{array}$ & $\begin{array}{r}-177.70 \\
(1.57)\end{array}$ & $\begin{array}{l}-1.041 \\
(0.27)\end{array}$ & $\begin{array}{r}-1.238 \\
(0.24)\end{array}$ \\
\hline \multicolumn{11}{|l|}{$\begin{array}{r}\text { 9-Year changes in gaps with respect to } \\
\text { structural benchmarks }\end{array}$} \\
\hline \multirow[t]{2}{*}{ Accounts } & $\begin{array}{r}20.560 \\
(0.15)\end{array}$ & $\begin{array}{r}0.755 \\
(0.04)\end{array}$ & $\begin{array}{r}61.100 \\
(0.44)\end{array}$ & $\begin{array}{r}-541.70 \\
(0.59)\end{array}$ & $\begin{array}{r}26.750 \\
(0.21)\end{array}$ & $\begin{array}{l}-0.513 \\
(0.03)\end{array}$ & $\begin{array}{r}45.290 \\
(0.38)\end{array}$ & $\begin{array}{r}-255.000 \\
(0.62)\end{array}$ & $\begin{array}{r}68.13 \\
(0.36)\end{array}$ & $\begin{array}{r}-77.36 \\
(0.36)\end{array}$ \\
\hline & & 95 & & 95 & & 98 & & 108 & & 108 \\
\hline Branches & $\begin{array}{r}2.294 \\
(1.05)\end{array}$ & $\begin{array}{l}-0.263 \\
(0.87)\end{array}$ & $\begin{array}{r}2.301 \\
(1.03)\end{array}$ & $\begin{array}{r}-13.560 \\
(0.73)\end{array}$ & $\begin{array}{r}2.146 \\
(1.01)\end{array}$ & $\begin{array}{r}-0.166 \\
(0.58)\end{array}$ & $\begin{array}{r}2.808 \\
(1.50)\end{array}$ & $\begin{array}{l}-6.582 \\
(1.39)\end{array}$ & $\begin{array}{r}3.3190 \\
(1.29)\end{array}$ & $\begin{array}{r}-2.170 \\
(0.70)\end{array}$ \\
\hline Observations & & 146 & & 146 & & 149 & & 169 & & 169 \\
\hline
\end{tabular}

This table shows the estimated coefficients, t-statistic (in parentheses), and number of observations corresponding to a cross-country OLS regression of each financial inclusion variable on a constant, an OIC dummy variable as well as its interaction with alternatively, $I B_{0}$, the total number of Islamic Banks, $I B_{1}$, total assets of Islamic Banks, both scaled by the adult population, or WBIB, a dummy variable indicating whther the country is classified as an Islamic banking country. Significance levels of 10 percent $(*), 5$ percent $\left({ }^{* *}\right)$, and 1 percent $(* * *)$ are also indicated. In the upper panel, the financial inclusion variables (Accounts, Branches, Credit to Firms and Credit to Small Firms) are defined as the Gap or difference between their observed levels and the structural benchmarks estimated by Feyen et al (2013) and they are evalued at the latest observation. In the lower panel of the table, the maximum change in the Gap (at most, over 9 years) is computed as the dependent variable. 


\section{REFERENCES}

Ahmed, Habib, 2002, "Financing Microenterprises: An Analytical Study of Islamic Microfinance Institutions.” Islamic Economic Studies 9 (2): 27-64.

Allen, Franklin, Asli Demirguc-Kunt, Leora Klapper, and María Soledad Martínez Pería, 2012, "The Foundations of Financial Inclusion: Understanding Ownership and Use of Formal Accounts," World Bank Policy Research Working Paper 6290 (Washington: World Bank).

Arshad Ahmed, 2013. Islamic Private Equity: Misunderstood, Islamic Finance News. Guide, Feb.

Bacha, O. I., and A. Mirakhor, 2013, Islamic Capital Markets: A Comparative Approach (pp. 1-448). (Singapore: John Wiley \& Sons).

Barajas, Adolfo, Ralph Chami, and Seyed Reza Yousefi, 2013, "The Finance-Growth Nexus Re-examined: Do All Countries Benefit Equally?" IMF Working Paper 13/130 (Washington: International Monetary Fund).

Barajas, Adolfo, Thorsten Beck, Era Dabla-Norris, and Seyed Reza Yousefi, "Too Cold, Too Hot, or Just Right? Assessing Financial Sector Development Across the Globe," IMF Working Paper 13/81 (Washington: International Monetary Fund).

Bhattacharya, Rina and Hirut Wolde, 2012, "Constraints on Growth in the MENA Region," IMF Working Paper 10/30 (Washington: International Monetary Fund).

Demirguc-Kunt, Asli, and Leora Klapper, 2012, "Measuring Financial Inclusion: The Global Findex Database," World Bank Policy Research Working Paper 6025 (Washington: World Bank).

Demirguc-Kunt, Asli, Leora Klapper, and, Douglas Randall, 2013, "Islamic finance and financial inclusion: measuring use of and demand for formal financial services among Muslim adults," Policy Research Working Paper Series 6642, (Washington: World Bank).

El-Gari, Mohamed A., 2004. "The Qard Hassan Bank.” Paper presented at the International Seminar on Nonbank Financial Institutions: Islamic Alternatives, jointly organized by Islamic Research and Training Institute, Islamic Development Bank, and Islamic Banking and Finance Institute, Malaysia, Kuala Lumpur, March 1-3.

Feyen, E., K Kibuuka and D. Sourrouille, 2013, "FinStats 2014: A ready-to-use tool to benchmark financial sectors across countries and time" World Bank mimeo (Washington).

Hassan, K., and K. Lewis, 2007, Handbook of Islamic Banking, (Cheltenham, UK: Edward Elgar Publishing).

International Finance Corporation (IFC), 2014, Islamic Banking Opportunities across Small and Medium-Sized Enterprises in MENA. Report, Cairo. Egypt. 
Jabr, H., 2003, "Islamic Banking in Palestine: Challenges and Prospects." An-Najah Univ. J. Res. (H.Sc), 17(1).

Kahf, Monzer, 2004, "Shari' ah and Historical Aspects of Zakah and Awqaf," Background paper prepared for Islamic Research and Training Institute, Islamic Development Bank (Jeddah).

Love, Inessa and María Soledad Martínez Pería, 2012, "How Bank Competition Affects Firms' Access to Finance," World Bank Policy Research Paper 6163 (Washington: World Bank).

Love, Inessa, María Soledad Martínez Pería, and Sandeep Singh, 2013, "Collateral Registries for Movable Assets: Does Their Introduction Spur Firms' Access to Bank Finance?” World Bank Policy Research Paper 6477 (Washington: World Bank).

Mohieldin, Mahmoud, Zamir Iqbal, Ahmed Rostom, and Xiaochen Fu. 2011. "The Role of Islamic Finance in Enhancing Financial Inclusion in Organization of Islamic Cooperation (OIC) Countries." Policy Research Working Paper WPS5920, (Washington: World Bank). Paper prepared for Islamic Research and Training Institute, Islamic Development Bank (Jeddah).

Organization for Economic Cooperation and Development (OECD). Venture Capital Development in MENA Countries- Taking Advantage of the Current Opportunity. MENA Investment Policy Brief. April 2006 (Paris).

Saadani, Y., Z. Arvai, and R. Rocha, 2010, "A Review of Credit Guarantee Schemes in the Middle East and North Africa Region," Policy Research Working Paper 5612, (Washington: World Bank).

Shamoradi A., H. Mumtaz R and Turk-Ariss and al. 2014 "An Overview of Islamic Finance," IMF Note.

UK Islamic Finance Secretariat (UKIFS), 2013, "UK the Leading Center of Western Islamic Finance." Financial Market Series. October (London).

World Bank, 2014, Financial Inclusion, Global Financial Development Report (Washington). 